\title{
Processos Estruturais e Direito à Moradia no Sul Global: Contribuições das Experiências Sul-Africana e Colombiana
}

\section{Structural Litigation and the Right to Housing in the Global South: Contributions from the South African and Colombian EXPERIENCES}

\section{Procesos Estructurales y Derecho a la Vivienda en el Sur- Global: Contribuciones de las Experiencias Sudafricanas y Colombianas}

\author{
Matheus Casimiro Gomes Serafim \\ Eduarda Peixoto da Cunha França* \\ Flavianne Fernanda Bitencourt Nóbrega*
}

\begin{abstract}
1 Introdução. 2 A resposta judicial às omissões políticas: os processos estruturais. 3 Judicializando o direito à moradia: as experiências sul-africana e colombiana. 3.1 A experiência sul-africana: em busca da democratização dos processos estruturais. 3.2 Colômbia e o caso dos deslocados internos: a Sentencia T-25/04. 4 Protegendo o direito à moradia pelos processos estruturais: contribuições sul-africanas e colombianas. 4.1 África do Sul: entre a deferência excessiva e a proteção de grupos vulneráveis. 4.2 Colômbia: ativismo dialógico, construtivismo constitucional e efeitos provenientes das sentenças estruturais. 5 Conclusão. Referências.
\end{abstract}

Doutorando em Direito Público pela Universidade do Estado do Rio de Janeiro (UERJ). Mestre e Graduado em Direito pela Universidade Federal do Ceará (UFC). Especialista em Filosofia e Teoria do Direito pela PUC-MG. Coordenador-geral do Núcleo de Pesquisa em Interpretação e Decisão Judicial (NUPID). Universidade do Estado do Rio de Janeiro, Rio de Janeiro, RJ, BR. E-mail: <mcgserafim@gmail.com>.http://orcid.org/0000-0002-3963-3783

* Doutoranda e Mestre em Direito pela Universidade Federal de Pernambuco (UFPE). Pesquisadora do Núcleo de Pesquisa em Interpretação e Decisão Judicial (NUPID). Universidade Federal de Pernambuco, Recife, PE, BR. E-mail: <eduardacunhapf@gmail.com>. http://orcid.org/0000-00017163-923X

*** Professora Permanente do Programa de Pós-Graduação em Direito (Mestrado e Doutorado) da UFPE, vinculada à linha de pesquisa "Justiça e Direitos Humanos na América Latina". Professora de Teoria Política e do Estado do Departamento de Direito Público Geral e Processual da UFPE. Coordenadora do Programa de Extensão "Acesso ao Sistema Interamericano de Direitos Humanos aSIDH" e líder do "Laboratório de Pesquisa em Desenhos Institucionais", ambos da UFPE. Coordenadora da Câmara de Conciliação, Mediação e Arbitragem (CCMA) da Faculdade de Direito do Recife da UFPE. Pós-doutorado no Max Planck Institute for Comparative and International Private Law - Hamburg. Doutora em Direito pela UFPE, com período sanduíche na Bucerius Law School - Hamburg - Alemanha. Mestre em Ciência Política e Mestre em Direito pela UFPE. Universidade Federal de Pernambuco, Recife, PE, BR. E-mail: <flavianne@gmail.com>. http://orcid.org/0000-0002-2349-0167 


\section{RESUMO}

Objetivo: $\mathrm{O}$ objetivo do presente artigo é investigar como os processos estruturais podem contribuir com o acesso à moradia, a partir da análise da experiência de dois países nos quais os processos estruturais têm sido utilizados para solucionar litígios relacionados ao acesso à habitação digna: Colômbia e África do Sul.

Metodologia: Como metodologia de pesquisa, além da tradicional análise documental e bibliográfica, adota-se uma abordagem qualitativa para estudar três casos paradigmáticos: Olivia Road e Joe Slovo, na África do Sul, e a Sentencia T-25, na Colômbia.

Resultados: Conclui-se, em suma, que ambas as experiências denotam a necessidade de que problemas sistêmicos relativos a direitos socioeconômicos e culturais, quando adjudicados, sejam resolvidos por meio de decisões estruturais, que podem produzir efeitos materiais e simbólicos.

Contribuições: A partir dos resultados, observa-se que: a) é recomendável que os magistrados adotem uma postura dialógica quando atuarem em processos estruturais; b) em casos estruturais, é interessante que o Poder Judiciário mantenha a jurisdição sobre o caso, acompanhando o desenvolvimento da execução da sentença; c) a participação pública garante ao processo estrutural transparência e aos magistrados, maior capacidade técnica, uma vez que, somente com a inclusão dos segmentos sociais atingidos pelo problema que se pretende superar, o juiz será capaz de proferir medidas condizentes com as reais necessidades do caso concreto.

Palavras-chave: África do Sul. Colômbia. Direitos Socioeconômicos e Culturais. Direito à moradia. Processos Estruturais.

\section{ABSTRACT}

Objective: The purpose of this article is to investigate how structural injunctions can contribute to access to housing, based on an analysis of the experience of two countries in which structural injunctions have been used to resolve disputes related to access to decent housing: Colombia and South Africa.

Methodology: As a research methodology, in addition to the traditional documentary and bibliographic analysis, a qualitative approach is adopted to study three paradigmatic cases: Olivia Road and Joe Slovo, in South Africa, and Sentencia T-25, in Colombia.

Results: It is concluded that both experiences show the need for systemic problems related to socioeconomic and cultural rights, when adjudicated, to be resolved through 
Processos estruturais e direito à moradia no sul global: contribuições das experiências sul-africana e colombiana

structural decisions, which can produce material and symbolic effects.

Contributions: From the results, it is observed that: a) it is recommended that the judges adopt a dialogical approach when acting in structural decision making; b) in structural decision making, it is interesting that the Judiciary maintains jurisdiction over the case, following the development of the execution of the sentence; c) public participation guarantees the structural injunctions transparency and, to the judges, greater technical capacity, since only with the inclusion of the social segments affected by the problem that is intended to be overcome will the judge be able to produce measures consistent with the real needs the concrete case.

Keywords: South Africa. Colombia. Economic, social and cultural rights. The right to housing. Structural Litigation.

\section{RESUMEN}

Objetivo: El propósito de este artículo es investigar cómo los procesos estructurales pueden contribuir al acceso a la vivienda, a partir de un análisis de la experiencia de dos países en los que se han utilizado procesos estructurales para resolver disputas relacionadas con el acceso a una vivienda digna: Colombia y Sudáfrica.

Metodología: Como metodología de investigación, además del análisis documental y bibliográfico tradicional, se adopta un enfoque cualitativo para estudiar tres casos paradigmáticos: Olivia Road y Joe Slovo, en Sudáfrica, y Sentencia T-25, en Colombia.

Resultados: En conclusión, se concluye que ambas experiencias denotan la necesidad de que los problemas sistémicos relacionados con los derechos socioeconómicos y culturales, al ser otorgados, sean resueltos a través de decisiones estructurales, las cuales pueden producir efectos materiales y simbólicos.

Contribuciones: De los resultados se observa que: a) se recomienda que los magistrados adopten una postura dialógica al actuar en procesos estructurales; b) en los casos estructurales, es interesante que el Poder Judicial mantenga la jurisdicción sobre el caso, luego del desarrollo de la ejecución de la sentencia; c) la participación ciudadana garantiza la transparencia del proceso estructural y, a los magistrados, una mayor capacidad técnica, ya que solo con la inclusión de los segmentos sociales afectados por el problema que se pretende superar el juez podrá producir medidas acordes con la realidad. necesita el caso concreto.

Palabras clave: Sudáfrica. Colombia. Derechos sociales, económicos y culturales. Procesos estructurales. 


\section{INTRODUÇÃO}

A discussão sobre os limites da intervenção jurisdicional no âmbito das políticas públicas não é inédita no Brasil, tampouco são os processos estruturais que, por sua vez, já ocorrem no País há décadas, principalmente, em primeira e segunda instâncias (VITORELLI, 2020, p. 67). A real novidade é a teorização sobre os processos estruturais e o estudo sobre como podem impactar o controle judicial de políticas públicas, fortalecida a partir de 2015, especialmente com o julgamento da medida cautelar da Ação de Descumprimento de Preceito Fundamental (ADPF) no 347/DF (BRASIL, 2015a) - ação estrutural que pretende reconhecer o Estado de Coisas Inconstitucional (ECI) do sistema prisional brasileiro.

Desde então, outras duas importantes ações estruturais foram ajuizadas no Supremo Tribunal Federal (STF): a ADPF no 682 (BRASIL, 2020a), que pretendia reconhecer o ECI do ensino jurídico superior, e a ADPF no 709 (BRASIL, 2020b), que objetiva sanar omissões do Poder Público no combate à pandemia da COVID-19 entre os povos indígenas. A matéria também tem recebido maior atenção do Legislativo, uma vez que alguns Projetos de Lei (PL) tentam regular o processo coletivo estrutural no País. Entre essas tentativas, cabe ressaltar o PL no 8.058/2014, atualmente em tramitação na Câmara dos Deputados, o qual pretende regular a intervenção judicial no âmbito das políticas públicas, reconhecendo que, nesses casos, o processo judicial terá características estruturais. Outro exemplo foi o Projeto de Lei do Senado (PLS) n 736/2015 (BRASIL, 2015b), já arquivado, o qual dispunha que o STF, ao reconhecer o ECI em alguma decisão, deveria determinar a realização de um Compromisso Significativo entre o Poder Público e os segmentos populacionais afetados.

Apesar do crescente interesse no tema, é dada pouca atenção ao potencial dos processos estruturais para promover o acesso à moradia, direito fundamental objeto de adjudicação em diversos países do chamado Sul Global ${ }^{1}$, como África do Sul, Argentina, Colômbia e Índia. Já no Brasil, por sua vez, o acesso à moradia digna é um problema estrutural presente em todo o território nacional. Segundo dados do Instituto Brasileiro

\footnotetext{
${ }^{1}$ A expressão Sul Global faz referência aos países da África, da América Latina e grande parte da Ásia e do Oriente Médio. O conceito de "Sul" não diz respeito exatamente a uma questão geográfica. É uma metáfora para representar o sofrimento humano em países das regiões periféricas e semiperiféricas do sistema-mundo moderno (que, após a II Guerra Mundial, foram denominadas de "Terceiro Mundo"), ocasionado pelo colonialismo, pelo capitalismo e pelo patriarcado e, também, uma forma de apresentar resistência a esses modos de opressão (SANTOS, 2010, p. 79). Estudar processos estruturais no Sul Global, portanto, permite que experiências de países, os quais têm uma história interconectada com o colonialismo, o neocolonialismo e uma estrutura social e econômica com grandes desigualdades em padrões de vida e acesso a recursos, sejam consideradas experiências ricas e promissoras, bem como que saberes produzidos acerca da temática se adequem às reais necessidades e realidades políticoinstitucionais de países que enfrentam contextos relativamente parecidos.
}

$151 \bullet \quad$ R. Opin. Jur., Fortaleza, ano 19, n. 32, p.148-183, set./dez. 2021 
Processos estruturais e direito à moradia no sul global: contribuições das experiências sul-africana e colombiana

de Geografia e Estatística (IBGE, 2020), dos mais de 65,5 milhões de domicílios ocupados pelos mais de 210 milhões de brasileiros, 5,127 milhões (7,8\%) correspondem a moradias irregulares. Segundo o mesmo estudo, as moradias irregulares contribuem para uma maior vulnerabilidade social, com possíveis consequências para os serviços de saúde e assistência social no caso do alastramento da COVID-19.

À vista disso, o presente artigo investiga as contribuições de dois países em que os processos estruturais já foram utilizados como meio de efetivar o direito à moradia: África do Sul e Colômbia. Com isso, pretende-se oferecer pontos de partida para se pensar acerca da utilização dessas demandas na resolução de litígios estruturais brasileiros relacionados à moradia.

Como metodologia de pesquisa, além da tradicional análise documental e bibliográfica sobre o tema, adota-se uma abordagem qualitativa para realizar o estudo de três casos principais: Olivia Road e Joe Slovo, na África do Sul, e sentença T-25, na Colômbia. Os casos sul-africanos foram selecionados pela sua relevância para a proteção do direito à moradia no país, visto que, em seus julgamentos, a Corte Constitucional desenvolveu um novo remédio estrutural - o Compromisso Significativo - que tem sido aplicado nos litígios posteriores a Joe Slovo. Já a sentença T-25, que tratou do acesso à moradia digna pelos deslocados internos na Colômbia, foi paradigmática para o aprimoramento do Estado de Coisas Inconstitucional, apresentando, pela primeira vez, critérios que deveriam ser utilizados para o seu reconhecimento. Vale ressaltar, ainda, que tanto o Compromisso Significativo quanto o ECI já foram mencionados no Brasil não só pela doutrina, mas também nos âmbitos judicial e legislativo, como na ADPF n ${ }^{\circ}$ 347 e no PLS no 736/2015.

Quanto à estrutura, o trabalho está dividido em três partes. No tópico 2, são apresentados os conceitos fundamentais que precisam ser esclarecidos antes de analisar os casos selecionados, como a definição de omissões políticas e processos estruturais. No tópico 3, estudam-se as experiências sul-africana e colombiana em processos estruturais cujo cerne é o acesso à moradia digna. Por fim, o tópico 4 analisa as contribuições que a experiência desses dois países pode dar para os processos estruturais no Brasil.

\section{A RESPOSTA JUDICIAL ÀS OMISSÕES POLÍTICAS: OS PROCESSOS ESTRUTURAIS}

O século XX trouxe uma profunda mudança na compreensão do papel do Estado em relação aos direitos fundamentais. $\mathrm{O}$ discurso do constitucionalismo liberal clássico, que valorizava a dimensão subjetiva dos referidos direitos e o dever estatal de abstenção, foi complementado com a implementação do Estado Social, responsável por atuar em prol dos direitos fundamentais por meio das políticas públicas (FRANÇA; SERAFIM; 
ALBUQUERQUE, 2021, p. 4). Além disso, o estudo da dimensão objetiva dos direitos fundamentais ressaltou que estes vinculam a atuação do Poder Público, o qual deve respeitá-los e continuamente agir em favor de sua implementação (NASCIMENTO, 2016, p. 68).

Nessa perspectiva, a previsão constitucional de um extenso rol de direitos não foi suficiente, entretanto, para assegurar a sua efetivação. Infelizmente, essa positivação teve caráter predominantemente simbólico, ocasionando o conceito de omissões políticas. Aqui, não há um vácuo normativo, ou seja, não se trata de completa ausência das normas infraconstitucionais destinadas à efetivação dos direitos fundamentais. $\mathrm{Na}$ verdade, pode existir ampla diversidade normativa tratando sobre determinado tema e, ainda assim, existir uma grave omissão política. Como explica Marmelstein (2015, p. 25), essas lacunas podem ser compreendidas como a falta de políticas públicas necessárias à proteção de direitos constitucionalmente assegurados, ocasionando-lhes profundas e reiteradas violações por parte do Poder Público.

Com a ampla positivação dos direitos econômicos, sociais e culturais (DESCs) e com o fortalecimento do Estado Social, os ordenamentos jurídicos passaram a prever instrumentos processuais que permitissem a tutela coletiva desses direitos. Isso porque o ajuizamento apenas de ações individuais, muitas vezes, baseado em direitos titularizados por uma coletividade, colaborava para a ocorrência de graves problemas, como insegurança jurídica, uma vez que decisões muito diferentes poderiam ser proferidas para pessoas que se encontravam em situação jurídica similar; inefetividade da tutela jurisdicional, que poderia obter melhores resultados ao tutelar a coletividade e não diversas demandas individuais fundadas no mesmo litígio; e promoção da economia processual, pois os esforços do Judiciário, então pulverizados em diversas ações individuais, poderiam ser centralizados em um único processo coletivo. Segundo Cappelletti e Garth (1988, p. 18-19), a criação de instrumentos processuais que permitem a tutela coletiva faz parte da segunda fase do acesso à justiça.

Nesse contexto, ainda que o processo coletivo represente um importante avanço para o acesso à justiça, ele ainda se demonstra insuficiente para uma plena tutela jurisdicional dos DESCs, uma vez que existem litígios coletivos com características muito específicas. Enquanto alguns processos coletivos podem ser solucionados com prestações pecuniárias ou com a realização de uma obrigação de fazer, por exemplo, outras demandas coletivas exigem algo a mais. Estas não podem ser resolvidas apenas com uma compensação pecuniária ou mediante realização de alguma prestação específica. $\mathrm{Na}$ verdade, exigem reformas mais profundas da realidade, implicando uma série de mudanças que devem ser executadas ao longo do tempo.

Assim, enquanto os litígios coletivos são conflitos entre interesses juridicamente relevantes em que uma das partes é vista como uma coletividade titular de direitos ou 
Processos estruturais e direito à moradia no sul global: contribuições das experiências sul-africana e colombiana

deveres, os litígios coletivos estruturais possuem essas mesmas características, mas com um importante elemento adicional: os direitos da coletividade não são violados por uma ação específica da outra parte, mas decorrem de um estado de coisas contrário ao direito, cuja mudança depende, geralmente, da reestruturação de uma política, programa ou instituição pública (VITORELLI, 2018, p. 340).

Desta feita, os litígios estruturais são caracterizados por uma interligação de interesses particulares em um mosaico complexo, de forma que só é possível atender ao interesse particular depois de determinar o quadro geral dos interesses envolvidos (PUGA, 2014, p. 48). Além disso, há a possibilidade de que as esferas jurídicas de terceiros, que não integram o conflito, sejam afetadas pela decisão judicial que intenta solucioná-lo (ARENHART, 2017, p. 423-424). Para Galdino (2020, p. 239-241), as referidas características fazem que os processos estruturais sejam multipolares ou policêntricos, isto é, tenham vários centros de interesse concorrentes, que serão diretamente impactados pela decisão judicial.

É importante ressaltar, ainda, que, em litígios estruturais, direitos individuais também podem ser violados. Pode-se citar como exemplo o grave problema estrutural do sistema prisional brasileiro, no qual os direitos à vida e à integridade dos indivíduos são ameaçados, bem como o direito à saúde de toda a coletividade que se encontra inserida naquele ambiente. Por essa razão, Vitorelli (2020, p. 42-45) argumenta que, em litígios coletivos, como é o caso dos litígios estruturais, é difícil separar as dimensões individual e coletiva dos direitos afetados.

Portanto, neste trabalho, a constante associação entre os DESCs e os processos estruturais não deve induzir o leitor à compreensão de que não existem direitos individuais violados em litígios estruturais. Centra-se a análise nos DESCs por sua especial dependência ${ }^{2}$ de prestações positivas do Estado e pela sua usual presença em litígios coletivos (especialmente os estruturais). Além disso, esses processos têm sido utilizados como importante mecanismo de efetivação dos DESCs no Sul Global, como no caso da Colômbia e da África do Sul.

\footnotetext{
${ }^{2}$ Fala-se em especial dependência, pois a diferença entre direitos individuais e sociais, em relação à necessidade de gastos públicos para a sua proteção, é apenas quantitativa. Como mostram Holmes e Sunstein (2019), a crença de que apenas os direitos socioeconômicos demandam gastos públicos é equivocada, visto que o Estado precisa investir em políticas públicas para proteger clássicos direitos individuais, como a vida e a propriedade. Pode-se falar em uma especial dependência dos DESCs em relação às políticas públicas, ou que estes demandam mais investimentos, mas isso não significa que os direitos individuais exigem apenas abstenções estatais. Ademais, o posicionamento dos autores é consoante ao argumento de Vitorelli. Quando o Estado elabora uma política pública, busca proteger os direitos de uma coletividade, sendo usual que haja direitos individuais e socioeconômicos protegidos pela mesma política. Por isso, quando se está diante de um litígio coletivo em que se questiona uma política pública, ainda que um direito socioeconômico seja a primeira justificativa para o controle judicial de políticas públicas, é possivel que direitos individuais também estejam sendo violados.
} 
Os litígios estruturais são um dado da realidade, o que significa que eles existem ainda que o Direito não forneça instrumentos processuais para que sejam tutelados coletivamente (VIOLIN, 2019, p. 219). Contudo, é possível que a ordem jurídica ocasione o recurso a um tipo de processo coletivo específico capaz de lidar com essa espécie de litígio: os processos estruturais. Tratando da questão, Vitorelli explica:

O processo estrutural é um processo coletivo no qual se pretende, pela atuação jurisdicional, a reorganização de uma estrutura, pública ou privada, que causa, fomenta ou viabiliza a ocorrência de uma violação a direitos, pelo modo como funciona, originando um litígio estrutural (VITORELLI, 2020, p. $60)$.

Para o autor, os processos estruturais têm, como ponto de partida, a sistemática violação aos direitos fundamentais, sendo que o objetivo não é apenas reparar os danos já ocasionados, mas também promover uma readequação das políticas públicas necessárias à efetivação dos direitos violados ou reorganizar estruturalmente as instituições responsáveis por realizá-las (VITORELLI, 2015, p. 564). No modelo tradicional de processo, opera o binômio direito-obrigação: caso seja comprovada a existência da violação de um direito, o Judiciário determina a sua reparação. A indenização dos segmentos populacionais afetados, no entanto, não soluciona a omissão política e, por consequência, não impede que as violações continuem ocorrendo (VITORELLI, 2015, p. 564). Para resolver o problema, o processo estrutural possibilita o tratamento da origem do litígio: a reestruturação de uma instituição pública.

Concorda-se com Vitorelli que, geralmente, os processos estruturais implicam a reestruturação de uma instituição pública. Contudo, reduzir o conceito somente a esses casos o tornaria excessivamente restritivo, deixando de englobar processos que costumam ser associados com os litígios estruturais, como em casos de danos ambientais decorrentes da atuação de entes privados. Por essa razão, concorda-se com Galdino (2020, p. 123) que, por sua vez, defende que os processos estruturais são instrumentos processuais que buscam transformar um estado de coisas A, violador de direitos fundamentais, em um estado de coisas B, promotor de direitos. Isso costuma implicar uma reestruturação de uma instituição pública, o que não é obrigatório.

Dessa forma, a expressão processo estrutural, neste trabalho, sempre fará referência aos processos coletivos estruturais de interesse público, os quais podem ser compreendidos como um conjunto ordenado de atos jurídicos destinados a obter uma tutela judicial coletiva, capaz de transformar, gradualmente, um estado de coisas A, violador de direitos fundamentais, em um estado de coisas $\mathrm{B}$, apto a promover os direitos que dele dependem. Assim, o interesse público desses processos decorre do fato de que a coletividade pleiteia a efetivação de direitos em face do Estado, o que costuma implicar uma reestruturação de políticas, programas ou instituições públicas. 
Processos estruturais e direito à moradia no sul global: contribuições das experiências sul-africana e colombiana

\section{JUDICIALIZANDO O DIREITO À MORADIA: AS EXPERIÊNCIAS SUL- AFRICANA E COLOMBIANA}

Esclarecidos os conceitos fundamentais para a pesquisa, analisam-se as experiências sul-africana e colombiana com processos estruturais cujo cerne é o acesso à moradia digna. Para isso, são estudados três casos principais: Olivia Road e Joe Slovo, da África do Sul, e a sentença T-25, da Colômbia.

\subsection{A EXPERIÊNCIA SUL-AFRICANA: EM BUSCA DA DEMOCRATIZAÇÃO DOS PROCESSOS ESTRUTURAIS}

A positivação de direitos socioeconômicos na Constituição sul-africana de 1996 revela o comprometimento com o chamado transformative constitucionalism, que pode ser compreendido como um projeto de longo prazo, no qual as instituições públicas têm o dever constitucional de transformar a realidade política e social do país, fazendo que as relações de poder sejam mais democráticas, participativas e igualitárias (KLARE, 1998, p. 150). No contexto sul-africano, a promessa do constitucionalismo transformador não pode ser alcançada enquanto a maioria da população continuar sem acesso às condições econômicas e sociais mínimas (PIETERSE, 2005, p. 156).

Nessa perspectiva, a Constituição sul-africana reflete o compromisso do processo democrático em reparar as injustiças que o apartheid criou, apontando para a proeminência do Legislativo e do Executivo na efetividade dessa transformação (RAY, 2016, p. 39). Apesar de o protagonismo caber aos poderes políticos, a Corte Constitucional detém um papel supervisor fundamental, a fim de assegurar que as garantias constitucionais sejam observadas (JIUN WEH; CHANG, 2009, p. 172-173). Desta feita, a atuação da Corte tem sido especialmente relevante na resolução de litígios estruturais cujo foco é o direito à moradia, previsto na seção 26(1) da Constituição de $1996^{3}$, sendo possivel destacar três casos paradigmáticos: Grootboom, Olivia Road e Joe Slovo. Aqui, foca-se em Olivia Road e Joe Slovo, mas é importante fazer uma breve apresentação de Grootboom, primeiro caso de direito à moradia levado à Corte Constitucional e base para os julgados posteriores.

Inicialmente, depreende-se que o caso Grootboom é um dos processos estruturais mais conhecidos pelos estudiosos de direito comparado, chegando Roux (2013, p. 280) a afirmar que a sua importância para os juristas sul-africanos equivale à relevância do

\footnotetext{
3 "26. Housing. (1) Everyone has the right to have access to adequate housing. (2) The state must take reasonable legislative and other measures, within its available resources, to achieve the progressive realisation of this right. (3) No one may be evicted from their home, or have their home demolished, without an order of court made after considering all the relevant circumstances. No legislation may permit arbitrary evictions." (ÁFRICA DO SUL, 1996, p. 1255).
} 
caso Brown v. Board of Education para os juristas norte-americanos. Cumpre destacar que Grootboom apresenta uma peculiaridade em suas análises. Enquanto autores estrangeiros, como Sunstein (2001, p. 221-222), costumam elogiar a decisão, muitos juristas sulafricanos são críticos à posição da Corte no caso, afirmando que o excesso de deferência ao Executivo permitiu que o grupo afetado pelo litígio permanecesse sem uma solução satisfatória (MBAZIRA, 2011, p. 61). Para os que pensam dessa forma, a maior prova de seu insucesso é que Irene Grootbom, autora da ação, morreu no aguardo de uma moradia digna, oito anos depois de obter vitória no Judiciário (RODRÍGUEZGARAVITO, 2011, p. 1681-1682).

Em Grootboom, uma comunidade de 900 pessoas que viviam em barracos foi expulsa de uma propriedade privada após terem se candidatado à moradia de baixo custo do governo. Com a expulsão, eles ocuparam um campo de esportes nas proximidades e montaram instalações improvisadas (KAMGA; HELEBA, 2012, p. 95). Tendo em vista a violação ao seu direito à moradia, Irene Grootboom e outros membros da comunidade ajuizaram uma ação contra as autoridades municipais e federais, requerendo que providenciassem moradias temporárias e outros serviços básicos (RAY, 2016, p. 51).

Ao julgar o caso, a Corte entendeu que o Estado possui a obrigação constitucional de assistir indivíduos que estão em situações de crise ou em condições de vida intoleráveis (ROUX, 2013, p. 291). A política habitacional deve desenvolver medidas emergenciais, ainda que temporárias, para aqueles que estiverem nessas condições. Assim, o Tribunal determinou que o Poder Público deveria criar e implementar, conforme os recursos disponíveis, um programa destinado a efetivar o direito à moradia adequada, capaz de providenciar socorro para aqueles que estariam vivendo em condições deploráveis (WESSON, 2004, p. 288). Ainda que a Corte tenha declarado a ineficiência da política habitacional desenvolvida e constatado a obrigação do Estado de resolver a situação emergencial, não estabeleceu qualquer ordem específica para o Executivo, tampouco determinou como as políticas públicas deveriam ser efetivadas (LIEBENBERG, 2001, p. 257), de modo que o comando judicial não foi materializado até hoje.

O segundo caso, bastante influenciado por Grootboom, foi Olivia Road. Entre os anos de 2002 e 2006, tornou-se comum a realização de despejos em massa nas periferias da cidade de Joanesburgo (WILSON, 2011, p. 135), a fim de efetivar programas de revitalização urbana. Como explica Cloete (2016, p. 78), durante o período do apartheid, o governo sul-africano conseguiu segregar a população negra no espaço urbano. Enquanto a minoria branca geralmente vivia mais perto dos centros das cidades, a maioria da população negra residia em regiões periféricas, nas quais era comum encontrar milhares de pessoas morando em prédios inadequados para a habitação. No 
Processos estruturais e direito à moradia no sul global: contribuições das experiências sul-africana e colombiana

plano de regeneração da cidade, datado de 2004, que atingiria 67.000 pessoas, é possível verificar algumas das justificativas utilizadas: prédios em más condições, aumento das moradias em condições insalubres e aumento da criminalidade nessas regiões (RAY, 2016, p. 111).

Nesse contexto, o caso Olivia Road tem início quando a cidade de Joanesburgo ajuíza uma ação no Tribunal Regional de Witwatersrand ${ }^{4}$, requerendo autorização judicial para despejar mais de 400 residentes de prédios que seriam reestruturados. $\mathrm{O}$ Tribunal Regional rejeitou o pedido de despejo do governo municipal, entendendo que a cidade violou a seção 26 da Constituição, a qual assegura o direito à moradia, visto que pretendia despejar os moradores sem providenciar abrigos alternativos (ÁFRICA DO SUL, 2008a, p. 3). Após a decisão, o governo municipal apelou para a Suprema Corte de Apelação (SCA), que reverteu a decisão do Tribunal Regional e concluiu que os despejos eram autorizados pela Constituição. Em prol dos residentes, a SCA apenas determinou que a cidade tinha o dever de providenciar abrigo para aqueles que perdessem a sua residência (ÁFRICA DO SUL, 2008a, p. 2).

Recorrendo da decisão proferida pela SCA, os residentes conseguiram levar a ação até a Corte Constitucional, que aceitou o caso em maio de 2007. No dia 30 de agosto, a Corte expediu a primeira ordem para que um Compromisso Significativo ${ }^{5}$ fosse realizado entre as partes envolvidas no litígio. A decisão, redigida pelo juiz Zakeria Yacoob, determinou que:

A cidade de Joanesburgo e os demandantes devem se engajar significativamente assim que possivel, em um esforço para resolver as diferenças e dificuldades expostas nesta ação à luz dos valores da Constituição, dos deveres constitucionais e estatutários do município e dos direitos e deveres dos cidadãos em questão ${ }^{6}$ (ÁFRICA DO SUL, 2008a, p. 5).

\footnotetext{
${ }^{4}$ Os Tribunais Superiores (High Courts) ocupam a segunda instância judicial da África do Sul, com jurisdição em uma área delimitada geograficamente. Já o Supremo Tribunal de Apelação (Supreme Court of Appeal) equivale ao Superior Tribunal de Justiça no Brasil. Localizado em Bloemfontein, a SCA é a última instância para discussões acerca de matérias infraconstitucionais, cujas decisões serão vinculantes para todos os tribunais inferiores (SAMPAIO, 2016, p. 87).

${ }^{5}$ É importante ressaltar que a expressão Compromisso Significativo não é a tradução mais precisa para o termo Meaningful Engagement. Isso porque existem julgados, como Olivia Road, em que a Corte utiliza a expressão engagement com o fito de enaltecer a necessidade de as partes se engajarem significativamente na resolução do problema estrutural, colaborando entre si e atuando em boa-fé. Por outro lado, a expressão Compromisso, ainda que possa ser um dos sentidos da palavra engagement, ressalta mais o resultado da negociação do que o esforço conjunto para produzi-lo. À vista disso, acredita-se que a expressão Engajamento Significativo seria a mais adequada para expressar o sentido pretendido pela Corte ao utilizar o Meaningful Engagement. No entanto, tendo em vista que a doutrina brasileira tem adotado a tradução "Compromisso Significativo", sendo essa a mesma expressão utilizada no Projeto de Lei do Senado (PLS) no 736/2015, que tentava transplantar o instituto para o Brasil, preferiu-se manter a tradução usual no corpo do texto.

6 "The City of Johannesburg and the applicants are required to engage with each other meaningfully and as soon as it is possible for them to do so, in an effort to resolve the differences and difficulties aired in
} 
Após dialogarem por alguns meses, as partes chegaram a um acordo parcial. Entre outras determinações, o governo municipal concordou em não realizar o despejo e implementar medidas que melhorassem os prédios e a vida dos seus moradores, como limpeza da área residencial, acesso à água e ao saneamento básico (LIEBENBERG, 2012, p. 15). O governo municipal também concordou em reformar vários outros prédios localizados na periferia da cidade, fornecendo serviços públicos essenciais para os moradores da região, além de limitar quaisquer taxas de aluguel a $25 \%$ da renda mensal dos ocupantes. Por fim, o governo aceitou continuar o diálogo em longo prazo, buscando soluções para os problemas de moradia (SOUZA NETO, 2018, p. 110).

Os resultados de Olivia Road influenciaram diretamente na decisão da Corte em Joe Slovo. Em 2008, a cidade de Cape Town, capital da província de Western Cape, iniciou a implementação do N2 Gateway, projeto de desenvolvimento urbano destinado a construir casas de baixo custo aos moradores, mas que oferecessem adequadas condições de vida (MCLEAN, 2010, p. 224). O projeto fazia parte da política Breaking New Ground $(\mathrm{BNG})^{7}$, adotada pela África do Sul desde 2004 como tentativa de aprimorar as residências das periferias do país, em resposta ao caso Grootboom (RAY, 2016, p. 119). A comunidade de Joe Slovo, com mais de 20.000 residentes, seria diretamente afetada pelo N2 Gateway.

Desta feita, Joe Slovo era um dos maiores assentamentos informais da cidade de Cape Town, um verdadeiro símbolo de marginalização, exclusão econômica e desigualdade social (CHENWI, 2014, p. 188). A sua ocupação teve início nos anos 1990, e, como explica Kotzé (2016, p. 77-78), as casas da comunidade eram precárias, construídas com materiais inflamáveis e carentes de serviços públicos básicos, como acesso à água potável e ao saneamento básico.

Geralmente, reformas como as propostas pelo projeto N2 Gateway não demandam a remoção dos moradores, sendo realizadas com a sua presença no local. Nesse caso, contudo, o governo optou por uma reforma mais ampla, o que exigiria a realocação dos moradores de Joe Slovo para a região de Delft. Antes de iniciá-la, o governo municipal fez algumas reuniões com os moradores da comunidade. A finalidade não era dialogar para construir uma solução para o problema, visto que ela já estava pronta, mas esclarecê-los sobre o que havia sido decidido e como o plano seria implementado. Muitos residentes concordaram com o plano, uma vez que a cidade e a empresa responsável pela regeneração urbana, Tubelhisha Homes, asseguraram que a

this application in the light of the values of the Constitution, the constitutional and statutory duties of the municipality and the rights and duties of the citizens concerned.".

${ }^{7}$ O BNG é um plano nacional do governo sul-africano, criado em 2004, com o intuito de erradicar as moradias informais no país, no menor tempo possível. Com base nele, foram desenvolvidas várias políticas de reestruturação urbana, para reformar assentamentos informais, como no caso de Joe Slovo. (ÁFRICA DO SUL, 2004).

159• R. Opin. Jur., Fortaleza, ano 19, n. 32, p.148-183, set./dez. 2021 
Processos estruturais e direito à moradia no sul global: contribuições das experiências sul-africana e colombiana

maior parte dos moradores poderia retornar para Joe Slovo, pagando aluguéis bem mais baixos (PILLAY, 2012, p. 724). Porém, quando a primeira das três fases do projeto foi concluída, nenhuma das novas casas foi destinada aos moradores.

Decepcionados com as promessas que não foram cumpridas, os residentes organizaram protestos formais e informais com o objetivo de impedir o prosseguimento do N2 Gateway. Tentando contornar a situação, a cidade de Cape Town recorreu ao Tribunal Regional para assegurar o despejo dos residentes. O Tribunal ordenou que as realocações deveriam continuar, afirmando também que o governo municipal já havia dedicado esforço suficiente para dialogar com os moradores (KOTZÉ, 2016, p. 79).

Com base nessa decisão, os residentes apelaram diretamente para a Corte Constitucional, que produziu duas decisões sobre o caso. A primeira, feita em 2009, e chamada de Joe Slovo I, levou em consideração que, diferentemente de Olivia Road, em Joe Slovo, a realocação dos moradores fazia parte de uma política pública especificamente destinada a assegurar o direito à moradia dos próprios residentes, garantindo-lhes também uma moradia temporária (RADEBE, 2013, p. 130). Dessa forma, a Corte autorizou a realocação dos moradores, determinando, entretanto, que, antes que o N2 Gateway pudesse prosseguir, seria necessária a realização de um Compromisso Significativo entre a comunidade e a cidade para decidir a melhor forma de implementar o projeto.

Ao utilizar o Compromisso Significativo, a Corte evitou a adoção de uma postura excessivamente deferente. Primeiro, fixou parâmetros e objetivos que deveriam guiar as negociações das partes envolvidas. A lista de metas a serem alcançadas incluía:

Primeiro, a ordem desta Corte impõe uma obrigação aos demandados de garantir que $70 \%$ dos novos lares construídos no local do assentamento informal Joe Slovo são alocados a essas pessoas que atualmente residem lá ou que foram residentes, mas se mudaram após o lançamento do N2 Gateway Housing Project. Em segundo lugar, a ordem desta Corte especifica a qualidade do alojamento temporário em que os ocupantes serão alojados após o despejo; e terceiro, a ordem deste tribunal exige um processo contínuo do envolvimento entre os residentes e os demandados em relação ao processo de realocação ${ }^{8}$ (ÁFRICA DO SUL, 2008b, p. 3).

Em segundo lugar, a Corte decidiu reter a sua jurisdição sobre o caso, exigindo que as partes reportassem os andamentos e os resultados do diálogo. Assim, permitia

\footnotetext{
8 "First, this Court's order imposes an obligation upon the respondents to ensure that $70 \%$ of the new homes to be built on the site of the Joe Slovo informal settlement are allocated to those people who are currently residente there or who were resident there but moved away after the N2 Gateway Housing Project had been launched. Secondly, this Court's order specifies the quality of the temporary accommodation in which the occupiers will be housed after the eviction; and thirdly, this Court's order requires an ongoing process of engagement between the residents and the respondents concerning the relocation process.".
} 
que, caso houvesse alguma ilegalidade no processo, as partes pudessem retornar à Corte, requisitando a sua interferência. Ray (2016, p. 121) explica que as duas medidas foram adotadas para pressionar a cidade de Cape Town a manter um diálogo efetivo com a comunidade afetada e para que o governo municipal reconsiderasse a decisão de realocálos para Delft.

Iniciado o diálogo com os moradores, a cidade de Cape Town decidiu rever o seu posicionamento. Após o caso ser levado à Corte, a província de Western Cape, até então controlada pelo Congresso Nacional Africano, passou a ser governada pela Aliança Democrática, que obteve o controle sobre os recursos públicos destinados aos programas de habitação (TAMBWE, 2018, p. 26-27).

Tendo em vista os parâmetros estabelecidos pela Corte, o novo governo concluiu que seria viável seguir com o N2 Gateway sem precisar remover os residentes de suas moradias, fazendo todos os aprimoramentos necessários no assentamento, a fim de manter os moradores em suas residências (CHENWI, 2014, p. 190). É importante ressaltar que esse era o desejo dos moradores desde o início do litígio. Analisando o desfecho do caso, Pillay (2012, p. 750) defende que a interpretação substancial do direito à moradia - com detalhadas especificações que deveriam ser seguidas pelo governo municipal - e a retenção da jurisdição para supervisionar as negociações proporcionaram o resultado positivo obtido. Dessa forma, a Corte conseguiu não só promover o diálogo entre as partes, mas, indiretamente, pressionar o governo municipal a rever a sua decisão inicial.

Assim, considerando que não havia mais necessidade de realocação dos moradores para que o projeto e outras reformas prometidas pelo Poder Público fossem realizadas, a Corte, em 2011, revogou a autorização para o despejo daqueles, caso que ficou conhecido como Joe Slovo II (ÁFRICA DO SUL, 2011).

\subsection{COLÔMBIA E O CASO DOS DESLOCADOS INTERNOS: A SENTENCIA T- $25 / 04$}

A principal referência da Constituição Colombiana a um direito habitacional encontra-se em seu artigo $51^{9}$, que dispõe que cada colombiano tem o direito à moradia adequada, de modo que caberá ao Estado estabelecer as necessárias condições para fazer esse direito eficaz e promover políticas sociais orientadas a proporcionar habitação, sistemas adequados de financiamento de longo prazo e formas associativas de execução desses programas habitacionais.

\footnotetext{
9 “Artículo 51. Todos los colombianos tienen derecho a vivienda digna. El Estado fijará las condiciones necesarias para hacer efectivo este derecho y promoverá planes de vivienda de interés social, sistemas adecuados de financiación a largo plazo y formas asociativas de ejecución de estos programas de vivienda." (COLOMBIA, 1991, p. 26).
}

161 R. Opin. Jur., Fortaleza, ano 19, n. 32, p.148-183, set./dez. 2021 
Processos estruturais e direito à moradia no sul global: contribuições das experiências sul-africana e colombiana

É interessante notar, entretanto, que o direito à moradia não está previsto no rol de direitos que contam com eficácia imediata enunciados no artigo $85^{10}$ da Constituição do país. Não obstante essa constatação, sua adjudicação, perante a Corte Constitucional Colombiana (CCC), não tardou a acontecer.

Contudo, a construção da percepção de que o direito à moradia deveria vincular ações estatais compatíveis com a busca de sua concretização demandou um processo gradual de superação de entendimentos jurisprudenciais. Isso se justifica porque, inicialmente, com a Sentencia T-251/95, a CCC declarou a ausência de eficácia imediata do referido direito, argumentando que este estava sujeito à cláusula do desenvolvimento progressivo e, portanto, vinculado a uma espécie de condição viabilizadora cuja implementação caberia somente ao Poder Executivo (VALLE; GOUVEA, 2014, p. 221).

$\mathrm{O}$ primeiro avanço na proteção do direito à moradia ocorreu quando a CCC reconheceu existir um vínculo intrínseco entre a moradia digna e os direitos positivados no rol do artigo 85. A expressão utilizada pela Corte fazia referência a uma tutela de direitos "por conexão", extraindo uma relação simbiótica entre um direito socioeconômico (moradia) e um direito à liberdade, de modo que a violação ao primeiro implicaria, necessariamente, em uma violação ao segundo (VALLE; GOUVEA, 2014, p. 222).

Em decisões posteriores, a CCC declarou o dever do Estado de providenciar acesso a programas de habitação, tendo em vista o interesse público no enfrentamento do déficit habitacional e na proteção da dignidade humana, que poderia ser comprometida pela condição de desabrigado. Esse entendimento firmou-se nas Sentencias T-495/95 e T-791/04, com a sinalização, por parte da Corte, de que se fazia necessária a construção de uma política pública capaz de viabilizar o acesso à moradia, fosse por meio da entrega de unidades habitacionais ou pela facilitação do financiamento destas (VALLE; GOUVEA, 2014, p. 224).

A grande virada jurisprudencial, entretanto, ocorreu com a prolação da Sentencia T-985/01, na qual a CCC realizou uma divisão entre dois níveis distintos do direito à moradia: 1) um no qual se observava um claro viés de justiça distributiva; 2) e outro que poderia ser compreendido nas iniciativas públicas concretas de planejamento e oferta de planos e políticas que permitem a fruição plena do referido direito por todos os colombianos, planos esses já anteriormente tidos como exigíveis da Administração (VALLE; GOUVEA, 2014, p. 224).

Assim, enquanto o segundo nível poderia ser subordinado, em alguma medida, aos recursos estatais disponíveis e a outras variáveis, o primeiro seria revestido de eficácia imediata. Por meio desse entendimento, distinguir-se-ia o núcleo essencial do direito à

10 "Artículo 85. Son de aplicación inmediata los derechos consagrados en los artículos 11, 12, 13, 14, 15, 16, 17, 18, 19, 20, 21, 23, 24, 26, 27, 28, 29, 30, 31, 33, 34, 37 y 40.” (COLOMBIA, 1991, p. 26). 
moradia e uma zona subsidiária, que estaria sujeita à implementação progressiva (VALLE; GOUVEA, 2014, p. 224).

Essa divisão levantou a discussão acerca de como identificar as situações que poderiam ser acobertadas pela cláusula de eficácia imediata e as que não poderiam. Logo, em vez de ocupar-se em definir o direito à moradia em si, a Corte passou a realizar a tarefa de designar as situações que mereciam proteção por meio do posicionamento de aplicabilidade imediata.

Nesse sentido, a Sentencia T-25/04 tratou sobre uma grave crise humanitária: a situação das vítimas do deslocamento forçado na Colômbia ${ }^{11}$ - que ensejava a violação, entre outros, do direito à moradia de diversas famílias colombianas - as quais, em razão dos conflitos armados internos, tinham que se deslocar de suas casas, a fim de preservar sua sobrevivência.

Na oportunidade, a Corte Constitucional do país enfrentou 105 ações de tutela, todas relacionadas à inadequação ou à insuficiência das políticas públicas destinadas a lidar com a população deslocada internamente, afirmando a existência de uma obrigação geral do Estado na tomada de ação especificamente em relação àquele universo de desabrigados, com a garantia de um nível mínimo de proteção aos atingidos e prevenção da regressão no que concerne às providências já tomadas (GIUPPONI, 2010, p. 84).

Há aproximadamente trinta anos, o país enfrentava um quadro de violência generalizada proveniente de disputas pelo poder envolvendo o governo, organizações paramilitares de extrema direita e esquerda, narcotraficantes, microtraficantes e criminosos (COLOMBIA, 2004, p. 54), que surtia efeitos negativos, sobretudo na população mais pobre e vulnerável.

Assim, além dos déficits de moradia relacionados à crise econômica e a outras disfuncionalidades sociais, o deslocamento forçado de pessoas na Colômbia e a questão habitacional a ele relacionada apresentavam-se como uma consequência colateral da atuação de grupos armados e suas disputas de poder, de modo que as diversas organizações paramilitares operantes no país haviam criado uma realidade na qual os conflitos armados eram rotineiros e o interesse estratégico de qualquer um desses grupos em assumir o comando de determinadas localidades obrigava os moradores de diversas cidades a terem que abandonar suas casas (VALLE; GOUVEA, 2014, p. 247).

Esse cenário, consequentemente, gerava um alto número de pessoas refugiadas, desabrigadas e em condições degradantes, as quais viviam, em sua maioria, em situações

\footnotetext{
${ }^{11}$ Nesse sentido, "O deslocamento forçado é um fenômeno típico de países que sofrem um quadro interno de violência, de forma que a população é obrigada a migrar dentro do território e a abandonar seus lares e suas atividades econômicas em virtude de ações violentas de grupos como as FARC (Forças Armadas Revolucionárias da Colômbia), que ameaçam sua integridade física, famílias, segurança e liberdade." (LIMA; FRANÇA, 2019, p. 225).
}

163• R. Opin. Jur., Fortaleza, ano 19, n. 32, p.148-183, set./dez. 2021 
Processos estruturais e direito à moradia no sul global: contribuições das experiências sul-africana e colombiana

de indigência e mendicância, abaixo da linha da pobreza ${ }^{12}$. Os dados divulgados pela ACNUR demonstravam que a Colômbia contava com 5.289 .753 pessoas desalojadas de suas residências, número superior ao Sudão, ao Iraque, ao Afeganistão e à Somália, países que seguem na ordem decrescente do ranking do número de vítimas deslocadas (GARAVITO; FRANCO, 2010, p. 15). Entre a população atingida, vale ressaltar que se destacavam grupos historicamente vulneráveis, como mulheres chefes de família, idosos, crianças e minorias indígenas e afrodescendentes (LIMA; FRANÇA, 2019, p. 227).

As estatísticas registradas na época revelavam uma situação de miséria e total violação de direitos, de forma que: 1) $92 \%$ da população deslocada tinha suas necessidades básicas insatisfeitas e $80 \%$ desta encontrava-se em situação de indigência; 2) 63,5\% viviam em condições inadequadas de moradia e $49 \%$ não contavam com serviços idôneos; 3) em 57\% das famílias deslocadas, havia uma deficiência nutritiva, o que significa, em outras palavras, que somente $43 \%$ das famílias deslocadas consumiam os níveis de calorias recomendados pelo Programa Mundial de Alimentos da ONU (PMA); 4) $25 \%$ das crianças entre seis e nove anos não frequentavam uma escola, e essa proporção, para pessoas entre 10 a 25 anos, era de 54\%; 5) ainda, no que concerne à saúde das vítimas do deslocamento forçado, a taxa de mortalidade da população deslocada era seis vezes superior à média nacional (COLOMBIA, 2004, p. 55).

O contexto acima exposto deu gênese a um grupo de vítimas que sofria para superar um déficit de pertencimento, uma vez que as guerras internas forçavam seu deslocamento arbitrário de locais nos quais suas raízes socioafetivas estavam arraigadas, bem como obrigavam essa população a integrar novos ambientes que não lhe eram familiares nem desejados (VALLE; GOUVEA, 2014, p. 227).

Somava-se a esse quadro a situação da população deslocada que ia morar nas ruas ou daqueles que ocupavam edificações irregulares e em áreas de risco, tudo isso em decorrência da falta de uma política pública coordenada para a solução do problema de moradia desses indivíduos (VALLE; GOUVEA, 2014, p. 227).

Desta feita, a situação calamitosa, atrelada à reiterada violação de direitos fundamentais e à constante omissão do poder público na proteção das vítimas deslocadas, fez que estas ajuizassem ações de tutela - diretamente ou por meio de associações representativas -, a fim de que fossem superadas as falhas e a inércia no atendimento aos seus direitos, especialmente os relacionados à vida, à moradia, ao trabalho, à saúde e à educação (COLOMBIA, 2004, p. 30-31).

Nas instâncias ordinárias, algumas ações foram denegadas com embasamentos como: a ausência de legitimidade das associações para representar as vítimas do

\footnotetext{
${ }^{12}$ Os verbos são utilizados no passado, pois fazem referência à situação calamitosa no país no período da prolação da sentença. Entretanto, o fenômeno do deslocamento interno ainda é uma realidade na Colômbia.
} 
deslocamento; a inadequação da ação de tutela ante a existência de outro remédio jurídico cabível (a ação de cumprimento); a não demonstração da violação concreta de direitos ou da omissão estatal sem justa causa; o longo prazo de decurso entre os pedidos administrativos e o ajuizamento das ações; a usurpação das atribuições de outros poderes; a impossibilidade fática de cumprimento das decisões, entre outros (COLOMBIA, 2004, p. 34-37).

Ao analisar esses processos, a Corte Constitucional Colombiana (CCC) superou os óbices processuais e analisou o mérito dessas ações, reconhecendo a existência de um grave "problema humanitário", uma verdadeira "tragédia nacional" ou, mais especificamente, um "estado de coisas inconstitucional" que, segundo a Corte, contrariava a racionalidade implícita ao constitucionalismo e fomentava uma violação aos DESCs (COLOMBIA, 2004, p. 86-87).

Assim, o Tribunal reconheceu o dever do Estado de proteger os direitos fundamentais das vítimas deslocadas. Argumentou, com base no artigo 13 da Constituição Colombiana, que o Estado deveria promover as condições para que a igualdade fosse real e efetiva, bem como adotar medidas em favor dos grupos discriminados ou marginalizados, protegendo, especialmente, aqueles que, por sua condição econômica, física ou mental, se encontrassem em circunstâncias de debilidade manifesta (COLOMBIA, 2004, p. 86-87). Em seguida, declarou o Estado de Coisas Inconstitucional, que possui como fundamento a violação repetida, sistêmica e constante de direitos fundamentais, cujos efeitos afetam um número significativo de pessoas, cuja solução requer a intervenção de distintas entidades para atender problemas de ordem estrutural (ROSA; CARMO, 2019, p. 189).

Após o reconhecimento do ECI, a Corte se pronunciou no sentido de que as autoridades estavam obrigadas, pelos meios que achassem interessantes, a corrigir as desigualdades sociais, a facilitar a inclusão e a participação dos setores frágeis, marginalizados e vulneráveis da população na vida econômica e social da nação e a estimular um melhoramento progressivo das condições materiais de existência dos setores hipossuficientes da sociedade (COLOMBIA, 2004, p. 5).

No que concerne aos deveres do Estado, dispôs que este deveria adotar e implementar políticas, programas ou medidas positivas para efetivar uma igualdade real de condições e oportunidades entre os associados e, ao fazê-lo, dar cumprimento às suas obrigações constitucionais de satisfação progressiva dos direitos econômicos, sociais e culturais básicas da população - em consonância com o que a jurisprudência constitucional vinha denominando de "cláusula de erradicação das injustiças atuais". Além disso, entendeu que o Estado deveria abster-se de avançar, promover ou executar políticas, programas ou medidas ostensivamente regressivos no campo dos direitos econômicos, sociais e culturais, que levassem clara e diretamente a agravar a situação de 
Processos estruturais e direito à moradia no sul global: contribuições das experiências sul-africana e colombiana

injustiça, exclusão ou marginalização que se pretendesse correto, sem impedir gradualmente e progressivamente o avanço em direção ao pleno gozo desses direitos (COLOMBIA, 2004, p. 6).

Por tratar de falhas graves e profundas do Estado, a decisão é classificada por Garavito e Franco (2010, p. 15) como uma "macrosentença” e como uma das mais significativas tentativas jurisdicionais de implementação de decisão. Os autores acompanharam durante seis anos o andamento do processo e observaram que a CCC manteve a jurisdição sobre o caso com o intuito de garantir o cumprimento de suas ordens por meio de oitenta e quatro decisões de seguimento e quatorze audiências públicas, nas quais foi avaliado o desempenho do Poder Público e ditadas novas ordens, objetivando proteger os direitos dos deslocados internos.

Nessa perspectiva, as ordens emanadas pelo Tribunal não buscaram especificar os detalhes das medidas que as autoridades públicas deveriam adotar para atender à população deslocada (como já havia acontecido em outras ocasiões, como na Sentencia C-700 de 1999) (GARAVITO; FRANCO, 2010, p. 12). As ordens objetivaram, tão somente, a superação do estado de coisas violador de direitos por intermédio da participação e envolvimento do Estado e da sociedade civil organizada na elaboração e aplicação de programas para enfrentar a crise que assolava a população deslocada (LIMA; FRANÇA, 2019, p. 230).

Garavito e Franco (2010, p. 12) apontam, nesse sentido, que a prolação de medidas gerais (e não específicas) com a adoção de mecanismos que permitiam o acompanhamento do público criou um espaço de diálogo e deliberação com alto potencial democrático.

Desta feita, a CCC alegou que a sua atuação não violou a separação de poderes prevista na Constituição Colombiana de 1991 nem interferiu incisivamente na atuação das demais autoridades públicas no que concerne ao cumprimento de seus deveres. $\mathrm{O}$ Tribunal, em contrapartida, apelou ao princípio constitucional da colaboração harmoniosa entre os diferentes ramos do Poder, pois argumentou ser esta a função do juiz constitucional em um estado social de direito, bem como a postura adequada ao enfrentamento de direitos com matriz notadamente prestacional (COLOMBIA, 2004, p. 15).

Reconhecendo as magnitudes do problema dos deslocamentos forçados na Colômbia e a natureza limitada dos recursos disponíveis para o Estado suprir as necessidades de suas vítimas, a Corte declarou ser obrigatório aceitar que, no momento de planejar e implementar uma determinada política pública de proteção para a população deslocada, as autoridades competentes deveriam realizar um exercício de ponderação e estabelecer áreas prioritárias nas quais seria prestada a atenção oportuna e eficaz para essas pessoas. Portanto, argumentou que a dimensão de desempenho de 
todos os direitos constitucionais de toda a população deslocada não poderia ser satisfeita concomitantemente e ao nível máximo possível, dadas as restrições materiais e as dimensões reais da evolução do fenômeno de deslocamento (COLOMBIA, 2004, p.7).

Desde a adoção das medidas estruturantes prolatadas pela Corte Constitucional, grande parte da população deslocada, que outrora se encontrava desamparada, não está mais desassistida nem sofrendo violações constantes e reiteradas de seus direitos fundamentais (LIMA; FRANÇA, 2019, p. 231-232). Entretanto, o deslocamento forçado de pessoas ainda é um fenômeno presente na realidade colombiana, o que leva a concluir que existe a necessidade da adoção de novas medidas na esfera política, pelos agentes públicos responsáveis, sobretudo para que retrocessos não aconteçam (DANTAS, 2019, p. 230).

A adjudicação do caso viabilizou, assim, uma melhora no gozo efetivo dos direitos da população deslocada e "uma redução no volume de novos casos, especialmente de desplazados em massa de uma mesma localidade" (CARDOSO, 2019, p. 543). Ademais, a intervenção da Corte possibilitou a formulação e implementação de novas políticas públicas; a inclusão das ONG’s litigantes nas audiências públicas e nos processos de seguimento; e uma considerável melhora do financiamento e prestação de alguns serviços à população deslocada (GARAVITO; FRANCO, 2010, p. 24). No que diz respeito aos efeitos simbólicos - aqueles que influenciam as concepções e opiniões coletivas acerca do problema (LIMA; FRANÇA, 2020, p. 70) -, pode-se apontar que o maior deles foi a mudança da percepção pública acerca dos deslocados internos, de forma que estes passaram a ser vistos como sujeitos de direitos que estavam sofrendo ameaças constantes e reiteradas às suas condições básicas de vida digna, tornando o problema do deslocamento forçado de pessoas algo grave e urgente.

\section{PROTEGENDO O DIREITO À MORADIA PELOS PROCESSOS ESTRUTURAIS: CONTRIBUIÇÕES SUL-AFRICANAS E COLOMBIANAS}

No último tópico do artigo, pretende-se apresentar os principais aprendizados e contribuições com as experiências colombianas e sul-africanas, denotando diretrizes que possam nortear os processos estruturais brasileiros que tratem sobre o direito à moradia.

\section{1 ÁFRICA DO SUL: ENTRE A DEFERÊNCIA EXCESSIVA E A PROTEÇÃO DE GRUPOS VULNERÁVEIS}

Landau (2012, p. 192), analisando a eficiência das intervenções judiciais em prol da efetivação de direitos socioeconômicos, aponta a importância de estudar a experiência sul-africana. Em sua opinião, a atuação da referida Corte Constitucional é 
Processos estruturais e direito à moradia no sul global: contribuições das experiências sul-africana e colombiana

um exemplo do que não deve ser feito em matéria de litígios estruturais. $\mathrm{O}$ autor argumenta, ainda, que as decisões estruturais dialógicas não são capazes de obter bons resultados, falhando em proteger os segmentos sociais mais carentes e marginalizados. Para Landau (2012, p. 245-246), a solução é uma intervenção mais firme por parte do Judiciário.

A partir dos casos estudados neste trabalho, defende-se que as conclusões de Landau estão equivocadas. De fato, é fundamental o estudo da experiência sul-africana em litígios estruturais, já que esse país adotou um modelo de remédio dialógico (SERAFIM, 2021, p. 59). Contudo, as conclusões de Landau se baseiam principalmente no caso Grootboom, deixando de lado outros julgados posteriores, como Olivia Road e Joe Slovo.

Nesse contexto, o caso Olivia mostra como o Judiciário pode viabilizar a participação de grupos ameaçados pelo despejo na solução do litígio estrutural. Ao determinar que as partes se engajassem significativamente para solucionar o problema, a Corte possibilitou que um grupo marginalizado e com pouca representação política pudesse interferir diretamente nas escolhas da Administração Pública, que estava disposta a ouvi-los e colaborar com a melhor solução do problema (CHENWI, 2014, p. 186). Além disso, a Corte, diferentemente do que ocorreu em Grootboom, reteve a jurisdição sobre o caso, exigindo que as partes reportassem o andamento das negociações, o que foi fundamental para pressionar o Poder Público a colaborar com a implementação da decisão.

A busca por estabelecer um diálogo com a coletividade afetada contribuiu para mitigar as usuais críticas feitas aos processos estruturais, como a ameaça à separação de poderes e a incapacidade técnica do Judiciário (MAKABA, 2018, p. 39). Nem sempre, os litígios estruturais possibilitam uma ampla participação do grupo afetado, já que a sua conflituosidade pode fazer que existam vários subgrupos, com interesses divergentes, dentro de uma coletividade mais ampla (VITORELLI, 2020, p. 28-29). Em litígios relacionados à moradia, especialmente em casos de moradores de uma comunidade que será despejada, o vínculo social existente entre eles diminui a clivagem dentro do grupo e facilita a participação, como ocorreu em Olivia. Esses conflitos podem ser enquadrados no que Vitorelli (2018, p. 335) chama de litígios locais, nos quais os membros do grupo "[...] compartilham algum tipo de laço de solidariedade social (sociedade como solidariedade), que as faz pertencentes a uma comunidade que se diferencia dos demais segmentos sociais.”.

A regra geral, no entanto, não será a Administração Pública atuando com a mesma boa vontade apresentada no caso Olivia. Um bom exemplo disso é Joe Slovo. Desde o início, a cidade de Cape Town esteve indisposta a dialogar ativamente com os moradores que seriam despejados, tendo como única preocupação tornar a sua remoção 
a mais breve e econômica possível. À vista disso, a Corte adotou um Compromisso Significativo mais rígido que o utilizado no caso Olivia, fixando metas e objetivos que deveriam nortear as negociações e impedindo que o despejo ocorresse até que um plano habitacional adequado fosse produzido. Do mesmo modo, repetindo a fórmula do caso Olivia, reteve a jurisdição sobre o caso, pressionando o governo municipal a colaborar com a implementação da decisão. Esse conjunto de fatores fez que a cidade revisse sua decisão inicial de despejar os moradores (PILLAY, 2012, p. 750), optando por realizar as reformas in situ, opção por estes desejada desde o início do litígio.

Assim, o caso Joe Slovo ensina que o Judiciário não pode apenas confiar na boa vontade estatal para construir um plano habitacional adequado, enquanto permite que um grupo vulnerável seja despejado. É necessário, também, estabelecer o que Dorf e Sabel (1998, p. 453) chamam de "medidas profiláticas", determinações de caráter temporário, adotadas para proteger os grupos mais vulneráveis ao passo que os atores envolvidos no litígio desenvolvem a solução definitiva para o problema a partir das medidas já estabelecidas. Em litígios relacionados à moradia, medidas de caráter protetivo - como a proibição de despejos enquanto um plano habitacional não for desenvolvido e o dever da Administração em preservar o mínimo existencial do grupo podem pressionar os órgãos públicos a colaborar com a implementação da decisão.

Constata-se, portanto, uma gradual evolução da Corte Constitucional sul-africana na tutela do direito à moradia. Em Grootboom, tão criticado por Landau, a Corte adotou ordens vagas e genéricas, evitando ao máximo intervir no âmbito de competências do Executivo (LAWRENCE, 2013, p. 31-32). Foi também nesse julgamento que se desenvolveu o critério da razoabilidade, o qual seria o parâmetro para avaliar a adequação constitucional de políticas públicas. Para a Corte, a sua tarefa seria analisar se as medidas adotadas pelo Estado para realizar os direitos socioeconômicos eram razoáveis e coerentes, capazes de implementá-los progressivamente, dentro dos limites orçamentários do Estado. Nessa lógica, o Judiciário não iria considerar a existência de alternativas mais desejáveis, favoráveis ou se o dinheiro poderia ser melhor gasto, mas apenas se as medidas adotadas são suficientemente razoáveis e coerentes (TAMBWE, 2018, p. 14-15).

Ainda que a Corte tenha declarado a ineficiência da política habitacional desenvolvida e constatado a obrigação do Estado de resolver a situação emergencial, não estabeleceu qualquer ordem específica para o Executivo, tampouco determinou como as políticas públicas deveriam ser efetivadas (LIEBENBERG, 2001, p. 257). Segundo Lawrence (2013, p. 31-32), a Corte errou por estabelecer medidas muito vagas e não detalhadas, além de ter se negado a reter a supervisão sobre o caso.

Por outro lado, em Olivia Road e Joe Slowo, a Corte tentou rever o seu posicionamento e manter o equilíbrio entre respeitar as competências do Executivo e 
Processos estruturais e direito à moradia no sul global: contribuições das experiências sul-africana e colombiana

proteger os grupos ameaçados de despejo. Para os juristas brasileiros, já acostumados com uma maior intervenção judicial em políticas públicas, pode parecer uma pequena evolução. Entretanto, para uma Corte que costuma adotar posições deferentes em questões relacionadas a políticas públicas (ROUX, 2005, p. 76-77), os avanços posteriores à Grootboom abrem caminhos para aprimorar a defesa de grupos vulneráveis e $\mathrm{o}$ acesso à moradia por meio de processos estruturais.

Em síntese, a experiência sul-africana mostra que, em casos de litígios estruturais relacionados ao direito à moradia, o diálogo institucional e a participação do grupo afetado podem contribuir com a resolução do problema e com a mitigação das críticas usualmente feitas aos processos estruturais. Por outro lado, a mesma experiência mostra que o respeito às atribuições da Administração Pública não pode se transformar em deferência, permitindo que grupos vulneráveis fiquem à disposição da discricionariedade estatal. Quando necessário, devem-se fixar medidas emergenciais em favor desses grupos - como a proibição de despejos e o dever do Estado de proteger o mínimo existencial do grupo até a criação e um plano de realocação -, estabelecer parâmetros normativos que conduzam os diálogos entre as partes (LIEBENBERG, 2018, p. 634) e reter a supervisão sobre a criação e implementação do plano de ação a ser realizado (SWANEPOEL, 2017, p. 134-135).

\subsection{COLÔMBIA: ATIVISMO DIALÓGICO, CONSTRUTIVISMO CONSTITUCIONAL E EFEITOS PROVENIENTES DAS SENTENÇAS ESTRUTURAIS}

O estudo da jurisprudência da Corte Constitucional Colombiana viabiliza a obtenção de informações importantes para os debates acadêmicos que envolvem políticas públicas, a atuação do Poder Judiciário nas questões relativas à alocação de recursos e os efeitos de suas decisões. Ademais, proporciona um campo fértil para a reflexão teórica e empírica sobre as inovações constitucionais no Sul Global, que vem recebendo menos atenção dos acadêmicos que a América do Norte e a Europa (GARAVITO; FRANCO, 2019, p. 23).

Uma das contribuições mais interessantes que pode ser retirada da análise do caso dos deslocados internos é a figura do "ativismo dialógico", que pode ser entendida como a postura judicial que visa a definir metas e caminhos para a implementação de políticas públicas por meio de um processo de construção compartilhado, no qual a Corte acompanha e monitora o progresso do cumprimento de sentença sem tomar para si as decisões mais importantes, que devem ser combinadas e acertadas com o Poder Público, as instâncias majoritárias e a sociedade civil (ALBUQUERQUE; SERAFIM, 2020, p. 653). 
Desta feita, decisões nas quais o Poder Judiciário adota uma postura que é, concomitantemente, ativa e dialógica, têm o potencial de desvelar situações que violam direitos fundamentais de grupos que, muitas vezes, são invisibilizados. A partir disso, em vez de prolatar decisões unilaterais e inflexíveis, engaja o Poder Público, as instâncias majoritárias e a sociedade civil organizada em um plano colaborativo, que visa a explorar o potencial de cada um no sentido de contribuir para a ultrapassagem do status quo vigente. Assim, o ativismo dialógico garante ao processo decisório transparência, democratização e uma dose de consequencialismo, uma vez que as medidas prolatadas pelo Poder Judiciário não serão proferidas “no vácuo”, ou seja, não são formuladas sem que os magistrados tenham um real conhecimento do caso (que só pode ser garantido a partir da participação).

Ao trazer a figura do "ativismo dialógico", o presente artigo não objetiva gerar discussões acerca da função contramajoritária do Poder Judiciário ou trabalhar as já tão referenciadas críticas acerca do judicial review. Pretende, tão somente, demonstrar um tipo de postura judicial que, quando adotada, pode provocar efeitos significativos na realidade social. Em outras palavras: discute-se o ativismo dialógico, pois acredita-se que essa postura tem o potencial de fomentar transformações sociais significativas em contextos de violações massivas e reiteradas a direitos fundamentais, causando um impacto considerável na vida das vítimas. Existe, portanto, um objetivo concreto em discutir uma tipologia abstrata.

Nesse sentido, Garavito et al. (2013, p. 12) aponta que a sentença T-025/04 teve alguns outros efeitos principais. $O$ primeiro (e mais imediato) foi o "efeito de desbloqueio". Para o autor, a prolação da sentença viabilizou um "desbloqueio" das burocracias estatais que obstacularizavam a prestação de medidas que fossem capazes de atender aos deslocados internos por parte do Estado. A CCC, ao ordenar que o governo realizasse uma política coerente para proteger os direitos dos deslocados internos e estabelecesse prazos para avaliar o progresso, usou os Direitos Sociais e Econômicos como "direitos desestabilizadores", ou seja, como pontos de apoio para romper a inércia institucional e impulsionar a ação governamental (GARAVITO et al., 2013, p. 12).

O segundo, por sua vez, foi o "efeito de coordenação". Para o jurista colombiano, as falhas estruturais nas políticas públicas que visavam a atender aos problemas dos deslocados internos eram frutos não só da inércia das instituições competentes, mas também da falta de coordenação entre elas. Ao determinar que essas instituições colaborassem no desenho, no financiamento e na execução de uma política pública unificada para os deslocados internos, a CCC promoveu um tipo de coordenação, tanto entre os órgãos administrativos diretamente responsáveis pela decisão quanto entre os órgãos indiretamente relacionados ao caso (GARAVITO et al., 2013, p. 14).

O terceiro efeito foi o "efeito de política pública". Segundo Garavito et al. (2013, 
Processos estruturais e direito à moradia no sul global: contribuições das experiências sul-africana e colombiana

p. 14), o julgamento T-025 teve efeitos notáveis no desenho de uma política nacional de longo prazo para os deslocados internos, e também no estabelecimento de mecanismos para implementá-las, financiá-las e supervisioná-las. De fato, um ano após a prolação da sentença, como resposta direta à primeira ordem do Tribunal, o governo aprovou um Plano Nacional de Assistência Integral à População Deslocada pela Violência (GARAVITO et al., 2013, p. 14).

O quarto efeito levantado pelo autor é o "efeito participativo". O processo de acompanhamento do julgamento T-025 abriu os procedimentos judiciais e a criação de políticas públicas para uma ampla variedade de participantes governamentais e não governamentais. Esse efeito material foi, em parte, uma consequência direta da sentença e também uma consequência indireta e inesperada. Desde o início, as ordens da CCC envolveram não apenas os principais órgãos administrativos responsáveis pela situação dos deslocados internos, mas também outros órgãos com responsabilidades nas esferas internacional, nacional e local (GARAVITO et al., 2013, p.15).

O quinto e último efeito da decisão da Corte Constitucional Colombiana, segundo o autor, foi o "efeito de enquadramento", que representa uma reconfiguração simbólica cujos efeitos vão além daqueles inter partes. Na Sentença T-025, e por meio do processo de acompanhamento, a CCC ajudou a enquadrar o problema do deslocamento forçado - que era considerado, no passado, uma sequela do conflito armado - como um problema de direitos humanos, problema este que demandava uma ação imediata por parte das autoridades públicas. Essa é uma consequência indireta da Sentença, pois diz respeito a sujeitos que vão além daqueles classificados como "deslocados internos", a exemplo da mídia, das organizações internacionais de direitos humanos e da opinião pública como um todo (GARAVITO et al., 2013, p. 17).

Um ponto que pode ser destacado enquanto aprendizado e que se relaciona diretamente ao direito à moradia é a questão do construtivismo constitucional, no sentido de que a Corte Constitucional Colombiana permitiu uma gradual construção dos parâmetros que definem o conteúdo do direito à moradia, atentando, ademais, aos seus próprios precedentes. $\mathrm{O}$ respeito aos precedentes e a construção de parâmetros capazes de balizar como um determinado direito deve ser protegido - sobretudo tratando-se de um direito socioeconômico - podem ser importantes para garantir segurança e estabilidade jurídica, bem como para evitar a litigância individualizada de direitos cuja faceta principal é a prestacional.

Ainda nesse sentido, destaca-se que, no exercício jurisdicional efetuado na Colômbia, não se pretendeu estabelecer um conceito abstrato para o direito à moradia, que pudesse ser aplicado de maneira uniforme a toda e qualquer situação. Ao contrário, cada um dos entendimentos firmados pela Corte adicionou um detalhe à configuração de um problema que é multifacetado, viabilizando novas reflexões acerca dos parâmetros 
que haviam sido definidos anteriormente. Ao rememorar seus precedentes, a Corte Constitucional Colombiana preserva a coerência entre as sucessivas decisões e permite conhecer o desenvolvimento de sua lógica decisória na matéria (VALLE; GOUVEA, 2014, p. 229).

Nisso, tem-se uma abordagem diferente daquela empreendida pelo Supremo Tribunal Federal, uma vez que, muitas vezes, o foco principal do Tribunal é a solução do caso em exame, sem a valorização e construção do histórico de desenvolvimento do conteúdo do direito em questão (LORENZETTO; KOZICKI, 2015, p. 624).

Assim, o percurso da CCC permite vislumbrar um paradoxo interessante: apesar do caráter mais "forte" do direito à moradia na Constituição brasileira - uma vez que possui eficácia imediata -, sua proteção vem sendo assegurada de forma minimalista pelo Poder Judiciário, enquanto, na Colômbia, apesar de esse direito não possuir eficácia imediata garantida pela Constituição, o Poder Judiciário vem interferindo de maneira significativa em sua proteção.

Uma forma de suprir o que lhe falta em eficácia concreta (e não aquela afirmada no campo normativo) pela via judicial seria a prolação de sentenças estruturais sobre o direito à moradia que fugissem da outorga específica para o caso individual (normalmente uma prestação financeira substitutiva).

Apesar da outorga da prestação pecuniária (a exemplo do "aluguel social" ${ }^{13}$ no Município do Rio de Janeiro) ser mais fácil do ponto de vista operacional, ela não enfrenta o problema da falta de moradia como mal endêmico nas grandes cidades, pois não apresenta soluções para estas questões: "onde construir moradias nos grandes centros urbanos?"; "como remover a população das áreas de risco?"; "como lidar com as invasões de áreas privadas?"; "como evitar loteamentos irregulares e impedir a reiteração dessas mesmas condutas por indivíduos anteriormente removidos e que reincidem nos mesmos padrões de ocupação irregular?"; “como mitigar os malefícios do processo de gentrificação urbana ${ }^{14}$ ?".

\footnotetext{
${ }^{13} \mathrm{O}$ aluguel social consiste em um recurso assistencial fornecido mensalmente com o intuito de atender, em caráter de urgência, famílias que estão desabrigadas, sem moradia. É um subsídio concedido provisoriamente, e a família beneficiada recebe um valor equivalente ao custo de um aluguel popular. Nesse sentido: "[...] o aluguel social tem por finalidade efetivar o direito à moradia daqueles que se encontram em situação de calamidade e de emergência, seja decorrente de grande deslizamento, seja em área declarada de risco, e daqueles que não mais permanecem em sua residência. Nesses termos, ele se impõe como uma das formas encontradas pelo Poder Público de firmar o direito à moradia, viabilizando a dignificação das pessoas vitimadas." (ROGAR; VIEIRA, 2018, p. 2270-2271).

${ }^{14} \mathrm{~A}$ gentrificação é um processo de transformação urbana que envolve a expulsão de moradores de bairros periféricos a fim de transformá-los em áreas nobres. Nesse sentido, "O fenômeno aprofunda a criminalização da pobreza: é comum os governos do mundo todo justificarem a remoção de favelas e pessoas de modo a combater o crime, para pacificar os assentos informais e para realizar supergentrificação. Em todos os casos, a justificação vem acompanhada de ampla aceitação social pelos extratos mais altos - e por, inclusive, aqueles não tão altos, porém que assumem uma posição favorável
}

173• R. Opin. Jur., Fortaleza, ano 19, n. 32, p.148-183, set./dez. 2021 
Processos estruturais e direito à moradia no sul global: contribuições das experiências sul-africana e colombiana

Assim, apesar da justiciabilidade do direito à moradia no Brasil e de o Poder Judiciário ter considerável independência e autoridade no cenário pátrio (sobretudo tendo em vista a cláusula de acesso à justiça, a Emenda Constitucional 45/04 e as multifunções que foram atribuídas ao Supremo Tribunal Federal no artigo 102 da Constituição Federal), a proteção do direito à moradia pela via judicial ainda se mostra tímida - diferindo da proteção de outros direitos socioeconômicos, por exemplo, o direito à saúde - e pouco voltada à resolução das raízes do problema.

$\mathrm{Na}$ Colômbia, de modo contrário, a falta de eficácia do direito à moradia não comprometeu ou obstou a atuação da CCC, que desenvolveu uma estratégia que aumentou o potencial transformativo de sua própria prática, a fim de aprimorar os programas públicos na área. A chave para que isso pudesse acontecer foi um intenso diálogo com as circunstâncias concretas de cada caso, o que demonstra que o direito à moradia não se manifesta de maneira uniforme. Logo, um direito que, na Colômbia, poderia ser considerado fraco foi fortalecido pela atuação do Poder Judiciário, e não pelo número de provimentos positivos que expediu, mas sim pelo enfrentamento da situação que fomentava a violação de direitos e pela parametrização que ofereceu à atuação estatal no que concerne à matéria.

Assim, o ativismo adotado pela CCC não consistiu em um padrão de comportamento de caráter adversarial em relação aos demais ramos do poder, e sim em uma estratégia de atuação dialógica voltada a aumentar as capacidades institucionais e coordenar esforços públicos, a fim de cumprir os compromissos constitucionais do Estado.

\section{CONCLUSÃO}

O constitucionalismo e a jurisdição constitucional, como características da prática política pós-moderna em Estados democráticos, contemplam a ideia de que, atualmente, um desenho institucional com ferramentas contramajoritárias (VALLE, 2014, p. 68) é uma forma de garantir vez e voz a grupos marginalizados que não seriam devidamente representados no processo político.

Assim, a universalização desse modelo trouxe a possibilidade de que conflitos relativos à proteção de direitos fundamentais fossem propostos perante tribunais que exercem a função de Corte Constitucional em muitas partes do mundo, permitindo que o constitucionalismo comparativo pudesse deslocar os textos fundamentais para o exame de exemplos reais na experiência jurisdicional deles decorrentes, ensejando o que

à higienização urbana - e sem que haja medidas dignas aos habitantes locais, como informação à população, despejo com prévio reassentamento, contraditório social, inexistência de coação, avisoprévio, medidas mínimas para garantir a participação democrática." (MARCO; SANTOS; MOLLER, 2020, p. 4). 
Slaughter (2003) convencionou chamar de "comunidade global entre cortes".

Esse intercâmbio de experiências proporciona a criação de um ambiente rico para a análise comparativa de jurisprudências e uma ferramenta baseada na construção do conhecimento por agregação, não só aumentando a capacidade técnica de órgãos contramajoritários - o que é importante, sobretudo, quando o objeto de análise envolve questões distributivas -, como também abrindo o leque de possibilidades para a utilização de institutos inovadores para a proteção de direitos fundamentais.

Nesse sentido, foram exploradas as experiências da África do Sul e da Colômbia no manejo de sentenças estruturais que dizem respeito ao direito à moradia.

Enquanto aprendizados que podem ser extraídos da experiência colombiana, tem-se, inicialmente, que a mera eficácia imediata de um direito não é suficiente para garantir a sua real proteção.

Segundamente, repara-se que a concessão de uma prestação pecuniária a um determinado indivíduo que pleiteia seu direito à moradia (ou qualquer outro direito socioeconômico e cultural que esteja sendo violado) representa uma medida meramente paliativa, visto que é incapaz de solucionar a real fonte de problemas sistêmicos, arraigados no âmago da sociedade. Ainda nesse sentido, vale a ressalva de que ações pseudoindividuais acentuam o risco de o acesso à justiça se tornar excludente, considerando que somente aqueles que provocam o Poder Judiciário têm seus pleitos atendidos, enquanto milhares de outras pessoas - que se encontram na mesma situação ou em uma ainda pior - ficam desamparadas. Sendo assim, parece ser mais válido conforme demonstrado na Sentencia T-25/04 - apostar em provimentos estruturais, uma vez que, adotando um ativismo dialógico (LIMA; FRANÇA, 2019, p. 218), juízes podem fomentar mudanças sociais significativas, visto que o plano de reestruturação será pensado em conjunto com a Administração Pública, as instâncias majoritárias, a sociedade civil organizada e o sistema de justiça.

O terceiro aprendizado que pode ser retirado da experiência colombiana é que os efeitos provenientes de sentenças estruturais são diversos e, enquanto uns podem ser imediatos, outros só podem ser percebidos ao longo do tempo. Ainda sobre isso, vale destacar que efeitos simbólicos são de extrema relevância, uma vez que possibilitam, muitas vezes, a mudança da percepção da população sobre um determinado problema, fazendo que este passe a ser visto como um problema de direitos humanos. Ademais, ainda funcionam no sentido de denunciar a urgência e gravidade de determinados cenários que incentivam a violação massiva e reiterada de direitos fundamentais.

Por fim, o quarto aprendizado da experiência colombiana diz respeito à construção daquilo que pode ser entendido como "mínimo existencial” do direito à moradia. Esse entendimento, certamente, pode ser aplicado aos demais direitos socioeconômicos e culturais, mas é relevante, sobretudo, no que concerne ao direito à 
Processos estruturais e direito à moradia no sul global: contribuições das experiências sul-africana e colombiana

moradia. Isso porque, no Brasil, esse direito é violado por diversas razões diferentes, a depender do estado da federação em que o litígio ocorra. Assim, parte da população brasileira pode ter seu direito à moradia violado por causa de questões, como a violência urbana, o processo de gentrificação, a falta de políticas públicas que atendam adequadamente aos desabrigados, os desastres naturais (a exemplo de Mariana e Brumadinho), entre outros. Desta feita, é importante, para uma melhor resolução do litígio, que o núcleo mínimo do direito à moradia seja averiguado a partir do caso em concreto.

Já os aprendizados que podem ser extraídos da experiência sul-africana são igualmente relevantes. Inicialmente, o remédio dialógico adotado pela Corte Constitucional do país mostra-se de grande valia para o tratamento de questões estruturais, sobretudo tendo em vista a necessidade de uma avaliação holística do problema, que demanda a participação de atores políticos e sociais.

Em segundo lugar, o caso Olivia demonstra a importância da participação pública - e, principalmente, dos grupos cujos direitos fundamentais estão sendo diretamente violados pelo status quo vigente - nos processos estruturais. Isso se justifica pelo fato de que os indivíduos, os quais originariamente, não conseguiriam ser representados da forma devida no processo em curso, tiveram a oportunidade de participar ativamente da construção da resolução do problema, criando um espaço colaborativo, inclusivo e capaz de mitigar as tradicionais críticas ao judicial review: a ameaça à separação dos poderes e a falta de expertise do Poder Judiciário.

Um terceiro aprendizado, a partir da experiência da Corte em Joe Slovo, é a importância de diferenciar respeito à separação de poderes e deferência excessiva. Para proteger o direito à moradia de grupos vulneráveis, o Judiciário não pode apenas confiar na boa vontade da atuação estatal, sendo necessário fixar medidas protetivas emergenciais para o grupo afetado, bem como parâmetros normativos para o diálogo e as metas que devem ser alcançadas.

Por fim, como quarta contribuição, os casos analisados permitem vislumbrar a relevância da manutenção da jurisdição em casos estruturais. Afinal, a imprecisão das medidas adotadas inicialmente faz que estas tenham que ser revisitadas periodicamente. Assim, a (in)disponibilidade dos atores envolvidos em colaborar e cumprir com sua parte no plano de reestruturação faz que estes precisem ser fiscalizados com frequência, a fim de que as partes não negligenciem ou descumpram suas obrigações.

\section{REFERENCIAS}

ÁFRICA DO SUL. Breaking New Groung. Pretória, 2004. Disponível em: http://housingfinanceafrica.org/app/uploads/South-Africa-Breaking-New-Ground-BN G.pdf. Acesso em: 10 mar. 2020.

R. Opin. Jur., Fortaleza, ano 19, n. 32, p.148-183, set./dez. 2021 
ÁFRICA DO SUL. Constituição (1996). Constitution Of The Republic Of South Africa No. 108 of 1996. Pretória, 1996. Disponível em: https://www.gov.za/sites/default/files/images/a108-96.pdf. Acesso em: 5 fev. 2021.

ÁFRICA DO SUL. Corte Constitucional da África do Sul. Occupiers of 51 Olivia Road, Berea Township, and 197 Main Street vs city of johannesburg. Joanesburgo, 2008a. Disponível em: http://www.saflii.org/za/cases/ZACC/2008/1.pdf. Acesso em: 9 mar. 2020.

ÁFRICA DO SUL. Corte Constitucional. Residents of Joe Slovo Community, Western Cape v Thebelisha Homes and Others (CCT 22/08). Braamfontein, 2008b. Disponível em: http://www.saflii.org/za/cases/ZAGPHC/2008/255.pdf. Acesso em: 23 mar. 2020.

ÁFRICA DO SUL. Corte Constitucional. Residents of Joe Slovo Community, Western Cape v Thebelisha Homes and Others (CCT 22/08). Joanesburgo, 2011. Disponivel em: http://www.saflii.org/za/cases/ZACC/2011/8.pdf. Acesso em: 23 mar. 2020.

ALBUQUERQUE, Felipe Braga; SERAFIM, Matheus Casimiro Gomes. A importância da participação pública nos processos estruturais: contribuições da teoria normativa de Susan Sturm. REI-Revista Estudos Institucionais, v. 6, n. 2, p. 643-665, 2020.

ARENHART, Sérgio Cruz. Processo multipolar, participação e representação de interesses concorrentes. In: ARENHART, Sérgio Cruz; JOBIM, Marco Félix (org.). Processos estruturais. Salvador: JusPodivm, 2017. p. 423-448.

BRASIL. Câmara dos Deputados. Projeto de Lei $n^{\circ}$ 8058/2014. Institui processo especial para o controle e intervenção em políticas públicas pelo Poder Judiciário e dá outras providências. Brasilia, $2014 . \quad$ Disponível em: https://www.camara.leg.br/proposicoesWeb/fichadetramitacao?idProposicao=687758. Acesso em: 3 fev. 2021.

BRASIL. Supremo Tribunal Federal. Arguição de Descumprimento de Preceito Fundamental No 347/DF. Relator: Ministro Celso de Mello. Diário Oficial da União, Brasilia, 2015a. Disponível em: http://portal.stf.jus.br/processos/detalhe.asp?incidente $=4783560$. Acesso em: 25 jul. 2019 .

BRASIL. Senado Federal. Projeto de Lei do Senado $\mathrm{n}^{\circ} 736 / 2015$. Altera as Leis $\mathrm{n}^{\circ}$ 9.882, de 3 de dezembro de 1999, e 13.105, de 16 de março de 2015, para estabelecer termos e limites ao exercício do controle concentrado e difuso de constitucionalidade pelo Supremo Tribunal Federal, dispor sobre o estado de coisas inconstitucional e o compromisso significativo. Brasília, 2015b. Disponível em: https://www25.senado.leg.br/web/atividade/materias/-/materia/124010. Acesso em: 2

177• R. Opin. Jur., Fortaleza, ano 19, n. 32, p.148-183, set./dez. 2021 
Processos estruturais e direito à moradia no sul global: contribuições das experiências sul-africana e colombiana

jan. 2020.

BRASIL. Supremo Tribunal Federal. Arguição de Descumprimento de Preceito Fundamental no 682. Relator: Ministro Ricardo Lewandowski. Diário Oficial da União, Brasília, 2020a. Disponível em: http://www.stf.jus.br/arquivo/cms/noticiaNoticiaStf/ anexo/ADPF682.pdf. Acesso em: 17 ago. 2020.

BRASIL. Supremo Tribunal Federal. Arguição de Descumprimento de Preceito Fundamental no 709. Relator: Ministro Luis Roberto Barroso. Diário Oficial da União, Brasília, 2020b. Disponível em: http://portal.stf.jus.br/processos/downloadPeca.asp?id $=15343710124 \&$ ext=.pdf. Acesso em: 31 out. 2020 .

CAPPELlETTI, Mauro; GARTH, Bryant. Acesso à Justiça. Tradução Ellen Gracie Northfleet. Porto Alegre: Sergio Antonio Fabris Editor, 1988.

CARDOSO, Evorah. Pretérito imperfeito da advocacia pela transformação social. Revista Direito e Práxis, v. 10, n. 1, p. 543-570, 2019.

CHENWI, Lilian. Democratizing the socio-economic rights-enforcement process. In: GARCÍA, Helena Alviar; KLARE, Karl; WILLIAMS, Lucy A. (ed.). Social and Economic Rights in Theory and Practice: Critical Inquiries. Nova York: Routledge Research In Human Rights Law, 2014. p. 178-196.

CLOETE, Clireesh Terry. A critical analysis of the approach of the courts in the application of eviction remedies in the pre-constitutional and constitutional context. 2016. 231 f. Dissertação (Mestrado) - Curso de Direito, Stellenbosch University, Stellenbosch, 2016.

COLOMBIA. Constituição (1991). Constituição de 1991. Constitución Política de Colombia. Bogotá: República de Colombia, 1991. Disponível em: https://www.corteconstitucional.gov.co/inicio/Constitucion\%20politica\%20de\%20Col ombia.pdf. Acesso em: 6 fev. 2021.

COLOMBIA. Corte Constitucional Colombiana. Sentença que declarou o Estado de Coisas Inconstitucional dos deslocados internos. Sentença T-25/04. Abel Antonio Jaramillo e outros e Red de Solidaridad Social e outros. Relator: Magistrado Manuel José Cepeda Espinosa. Bogotá, COLÔMBIA, 24 de janeiro de 2004. Disponível em: https://www.corteconstitucional.gov.co/relatoria/2004/t-025-04.htm. Acesso em: 13 dez. 2019.

DANTAS, Eduardo Sousa. Ações estruturais e o estado de coisas inconstitucional: a tutela dos direitos fundamentais em casos de graves violações pelo poder público. Curitiba: Juruá, 2019. 
DORF, Michael C.; SABEL, Charles F. A constitution of democratic experimentalism. Columbia Law Review, p. 267-473, 1998.

FRANÇA, Eduarda Peixoto da Cunha; SERAFIM, Matheus Casimiro Gomes; ALBUQUERQUE, Felipe Braga. Processos estruturais e COVID-19: a efetivação do direito à saúde em tempos de pandemia. Revista Culturas Jurídicas, v. 8, n. AOP, p. 129, 2021.

GALDINO, Matheus Souza. Processos Estruturais: identificação, funcionamento e finalidade. Salvador: Juspodivm, 2020.

GARAVITO, Cesar A. Rodriguez et al. El activismo dialógico y el impacto de los fallos sobre derechos sociales. Revista Argentina de Teoría Jurídica, v. 14, n. 2, p. 1-27, dez. 2013.

GARAVITO, Cesar A. Rodriguez; FRANCO, Diana Rodríguez. Cortes y cambio social: cómo la Corte Constitucional transformó el desplazamiento forzado en Colombia. Bogotá: Centro de Estudios de Derecho, Justicia y Sociedad, Dejusticia, 2010.

GARAVITO, César Rodríguez; FRANCO, Diana Rodríguez. Juicio a la exclusión: El impacto de los tribunales sobre los derechos sociales en el Sur Global. Buenos Aires: Siglo XXI Editores, 2019.

GIUPPONI, María Belén Olmos. La protección de las comunidades afrodescendientes en el sistema interamericano: reflexiones a la luz del caso de las comunidades de Jiguamiandó y de Curbaradó. REIB: Revista Electrónica Iberoamericana, v. 4, n. 2, p. 61-97, 2010.

HOLMES; Stephen; SUNSTEIN, Cass R. O custo dos direitos: por que a liberdade depende dos impostos. Tradução Marcelo Brandão Cipolla. São Paulo: WMF Martins Fontes, 2019.

INSTITUTO BRASILEIRO DE GEOGRAFIA E ESTATÍSTICA - IBGE. Quase dois terços das favelas estão a menos de dois quilômetros de hospitais. 2020. Disponível em: https://agenciadenoticias.ibge.gov.br/agencia-noticias/2012-agencia-de-noticias/noticias /27728-quase-dois-tercos-das-favelas-estao-a-menos-de-dois-quilometros-de-hospitais?utm_ source $=$ covid19\&utm_medium=hotsite $\&$ utm_campaign=covid_19. Acesso em: 26 mai. 2021.

JIUN WEH, J. R.; CHANG, W. C. The Changing Landscape of Modern Constitutionalism: Transitional Perspective. National Taiwan University Law Review, v. 4, no. 1, p. 145-183, 2009.

KAMGA, Serges Alain Djoyou; HELEBA, Siyambonga. Crescimento Econômico Pode Traduzir-se em Acesso aos Direitos? Desafios das Instituições da África do Sul para que o Crescimento Conduza a Melhores Padrões de Vida. SUR Revista Internacional de Direitos Humanos, v. 9, n. 17, p. 87-113, 2012. 
Processos estruturais e direito à moradia no sul global: contribuições das experiências sul-africana e colombiana

KLARE, Karl E. Legal culture and transformative constitutionalism. South African Journal on Human Rights, v. 14, n. 1, p. 146-188, 1998.

KOTZÉ, Tina. Effective relief regarding residential property following a failure to execute an eviction order. 2016. 229 f. Tese (Doutorado) - Curso de Direito, Stellenbosch University, Stellenbosch, 2016.

LANDAU, David. The reality of social rights enforcement. Harvard International Law Journal, v. 53, 2012.

LAWRENCE, Rosline. The impact of supervisory orders and structural interdicts in socio economic rights cases in South Africa. 2013. 84 f. Dissertação (Mestrado) - Curso de Direito, Universidade de Western Cape, Bellville, 2013.

LIEBENBERG, S. The right to social assistance: the implications of Grootboom for policy reform in South Africa. South African Journal of Human Rights, v. 17, n. 2, p. 232-257, 2001.

LIEBENBERG, Sandra. Engaging the paradoxes of the universal and particular in human rights adjudication: The possibilities and pitfalls of 'meaningful engagement'. African Human Rights Law Journal, v. 12, p. 1-29, 2012.

LIEBENBERG, Sandra. Participatory Justice in Social Rights Adjudication. Human Rights Law Review, v. 18, n. 4, p. 623-649, 2018.

LIMA, Flavia Danielle Santiago; FRANÇA, Eduarda Peixoto da Cunha. Ativismo dialógico x bloqueios institucionais: limites e possibilidades do controle jurisdicional de políticas públicas a partir da Sentencia T-025/04 da Corte Colombiana. Argumenta Journal Law, n. 31, p. 209-243, jul./dez. 2019.

LIMA, Flávia Danielle Santiago; FRANÇA, Eduarda Peixoto da Cunha. A justiciabilidade dos direitos socioeconômicos e culturais no Sul Global: Uma aproximação às teorias dialógicas de Landau, Tushnet e Dixon. Revista Eletrônica da Academia Brasileira de Direito Constitucional, v. 12, n. 22, p. 45-80, 2020.

LORENZETTO, Bruno Meneses; KOZICKI, Katya. Constituindo a constituição: entre paradoxos, razões e resultados. Revista Direito GV, v. 11, n. 2, p. 623-648, 2015.

MAKABA, Ipeleng Josephinah. Citizen participation and meaningful engagement as effective tools for good governance in policy-making and realisation of economic, social and cultural rights. 2018. 67 f. Dissertação (Mestrado) - Curso de Direito, University Of Pretoria, Pretoria, 2018.

MARCO, C. M. de; SANTOS, P. J. T.; MÖLLER, G. S. Gentrificação no Brasil e no contexto latino como expressão do colonialismo urbano: o direito à cidade como proposta decolonizadora. urbe. Revista Brasileira de Gestão Urbana, v. 12, 2020. https://doi.org/10.1590/2175-3369.012.e20190253. 
MARMELSTEIN, George. A eficácia incompleta das normas constitucionais: desfazendo um mal-entendido sobre o parâmetro normativo das omissões inconstitucionais. Revista Jurídica da Fa7, Fortaleza, v. 12, n. 1, p. 10-28, 2015.

MBAZIRA, Christopher. Grootboom: A paradigm of individual remedies versus reasonable programmes. Southern African Public Law, v, 26, n. 1, p. 60-80, 2011.

MCLEAN, Kirsty. Meaningful Engagement: One Step Forward or Two Back? Some thoughts on Joe Slovo. Constitutional Court Review, Johannesburg, v. 3, p.223-242, 2010 .

NASCIMENTO, F. A. S. Direitos Fundamentais e sua dimensão objetiva. Porto Alegre: Sergio Antônio Fabris, 2016.

PIETERSE, Marius. What do we mean when we talk about transformative constitutionalism? SA Public Law, v. 20, n. 1, p. 155-166, 2005.

PILLAY, A. Toward effective social and economic rights adjudication: The role of meaningful engagement. International Journal Of Constitutional Law, v. 10, n. 3, p. 732-755, 2012.

PUGA, Mariela. El litigio estructural. Revista de Teoría del Derecho de la Universidad de Palermo, v. 1, n. 2, p. 41-82, 2014.

RADEBE, Sibusiso Blessing. The protection of the right of access to adequate housing by the south african Constitutional Court. 2013. 190 f. Dissertação (Mestrado) - Curso de Direito, Stellenbosch University, Stellenbosch, 2013.

RAY, Brian. Engaging with Social Rights: Procedure, Participation, and Democracy in South Africa's Second Wave. Cambridge: Cambridge University Press, 2016.

RODRÍGUEZ-GARAVITO, César. Beyond the courtroom: The impact of judicial activism on socioeconomic rights in Latin America. Texas Law Review, v. 89, p. 1669. 1698, 2011.

ROGAR, Renata; VIEIRA, Patrícia Ribeiro Serra. O aluguel social como instrumento perene de dignificação da pessoa humana. Revista de Direito da Cidade, v. 10, n. 4, p. 2259-2288, 2018.

ROSA, André Luís Cateli; CARMO, Valter Moura do. A declaração do Estado de Coisas Inconstitucional frente às consequentes externalidades negativas. Revista Opinião Jurídica, Fortaleza, v. 17, n. 25, p. 177-202, 2019. DOI:10.12662/24476641oj.v17i25.p177-202.2019.

ROUX, Theunis. Legitimating Transformation: Political Resource Allocation in the South African Constitutional Court. In: GLOPPEN, Siri; GARGARELLA, Roberto; SKAAR, Elin. Democratization and the judiciary: the accountability function of courts

181• R. Opin. Jur., Fortaleza, ano 19, n. 32, p.148-183, set./dez. 2021 
Processos estruturais e direito à moradia no sul global: contribuições das experiências sul-africana e colombiana

in new democracies. London: Frank Cass Publishers, 2005. p. 66-80.

ROUX, Theunis. The Politics of Principle: the first South African Constitutional Court, 1995-2005. New York: Cambridge University Press, 2013.

SAMPAIO, Karinne F.. O controle e a implementação do direito à saúde: a jurisprudência da África do Sul. Revista Digital Constituição e Garantia de Direitos, v. 9, p. 85-109, 2016.

SANTOS, Boaventura de Souza. Para além do pensamento abissal: das linhas globais a uma ecologia dos saberes. In: SANTOS, B. S.; MENESES, M. P (org.). Epistemologias do Sul. São Paulo: Cortez, 2010. p. 31-83.

SERAFIM, Matheus Casimiro Gomes. Compromisso Significativo: contribuições sulafricanas para os processos estruturais no Brasil. 2021. 166 f. Dissertação (Mestrado em Direito) - Faculdade de Direito, Universidade Federal do Ceará, Fortaleza, 2021.

SLAUGHTER, Anne-Marie. A global community of courts. Harvard International Law Journal, v. 44, p. 191, 2003.

SOUZA NETO, Gentil Ferreira de. A força normativa da Constituição, a judicialização das políticas públicas e o Compromisso Significativo. 2018. 146 f. Dissertação (Mestrado) - Curso de Direito, Instituto Brasiliense de Direito Público, Brasília, 2018.

SUNSTEIN, Cass R. Designing Democracy: what constitutions do. New York: Oxford University Press, 2001.

SWANEPOEL, Philip. The potential of structural interdicts to constitute effective relief in socio-economic rights cases. 2017. 220 f. Dissertação (Mestrado) - Curso de Direito, Stellenbosch University, Stellenbosch, 2017.

TAMBWE, Giteya. The impact of the engagement principle on the right to have acces to adequate housing: from reasonableness to engagement. 2018. 58 f. Dissertação (Mestrado) - Curso de Direito, Universidade de Pretoria, Pretoria, 2018.

VALLE, Vanice Regina Lírio do; GOVÊA, Carina Barbosa. Direito à moradia no Brasil e na Colômbia: uma perspectiva comparativa em favor de um construtivismo judicial. In: ENCONTRO NACIONAL DO CONPEDI/UNIMOVEUFCS/FLORIANÓPOLIS, 23., 2014, Florianópolis. Anais [...] Florianópolis: CONPEDI, 2014. p. 222-248.

VALLE, Vanice Regina Lírio do. Judicial adjudication in housing rights in Brazil and Colombia: a comparative perspective. Revista de Investigações Constitucionais, v. 1, n. 2, p. 67-102, 2014.

VIOLIN, Jordão. Processos estruturais em perspectiva comparada: a experiência norte americana na resolução de litígios policêntricos. 2019. 256 f. Tese (Doutorado) - Curso 
de Direito, Universidade Federal do Paraná, Curitiba, 2019.

VITORELLI, Edilson. Levando os conceitos a sério: processo estrutural, processo coletivo, processo estratégico e suas diferenças. Revista de Processo, v. 284, p. 333-369, out. 2018.

VITORELLI, Edilson. Processo Civil Estrutural: teoria e prática. Salvador: Juspodivm, 2020.

VITORELLI, Edilson. O devido processo legal coletivo: representação, participação e efetividade da tutela jurisdicional. 2015. 719 f. Tese (Doutorado) - Curso de Direito, Ciências Jurídicas, Universidade Federal do Paraná, Curitiba, 2015.

WESSON, Murray. Grootboom and Reassessing: Beyond the Socioeconomic Jurisprudence of the South African Constitutional Court. South African Journal On Human Rights, v. 20, n. 2, p. 284-308, Jan. 2004.

WILSON, Stuart. Litigating Housing Rights in Johannesburg's Inner City: 2004 2008. South African Journal On Human Rights, v. 27, n. 1, p.127-151, Jan. 2011.

\section{NOTA}

Matheus Casimiro Gomes Serafim: foi responsável pela elaboração dos tópicos 2, 3.1 e 4.1, auxiliando na revisão final do artigo. Eduarda Peixoto da Cunha França: foi responsável pela elaboração dos tópicos 3.2 e 4.2, auxiliando na revisão final do artigo. Flavianne Fernanda Bitencourt Nóbrega: foi responsável pela introdução e conclusão, auxiliando na revisão final do artigo.

Como citar este documento:

SERAFIM, Matheus Casimiro Gomes; FRANÇA, Eduarda Peixoto da Cunha; NÓBREGA, Flavianne Fernanda Bitencourt Nóbrega. Processos estruturais e direito à moradia no sul global: contribuições das experiências sul-africana e colombiana. Revista Opinião Jurídica, Fortaleza, v. 19, n. 32, p. 148-183, set./dez. 2021. 